\title{
El rumbo de las reformas. \\ Hacia una nueva agenda
para América Latina Hacia una nueva agenda
para América Latina
}

\section{Joseph E. Stiglitz \\ Profesor de Economía \\ y Finanzas, \\ Graduate School of \\ Business, \\ Universidad de Columbia. \\ Premio Nobel de \\ Economía 2001 \\ Kb2120@columbia.edu}

En el artículo se esboza una nueva agenda para las reformas, que se concentra en lo que los países latinoamericanos pueden hacer en el régimen internacional actual, y se identifican las deficiencias de la agenda anterior: i) las reformas aumentaron la exposición de los países al riesgo, sin acrecentar su capacidad de enfrentarlo; ii) las reformas macroeconómicas no han sido equilibradas; iii) las reformas impulsaron la privatización y el fortalecimiento del sector privado, pero dieron escasa importancia al mejoramiento del sector público. Además, se argumenta a favor de formular un conjunto de políticas económicas que reflejen un mayor equilibrio entre los mercados y el Estado; que superen el excesivo énfasis en la inflación para atender más a la creación de empleos; que no se concentren tanto en la privatización de empresas existentes como en crear empresas nuevas; y que se alejen de la creencia en el goteo del crecimiento y centren la atención en la reducción de la pobreza, de manera que la agenda económica de reforma se ubique dentro del contexto más amplio de la transformación de la sociedad. 


\section{Introducción}

El experimento denominado de reforma está fracasando en América Latina. Después de un breve repunte a principios del decenio de 1990, el crecimiento se ha hecho más lento (gráfico 1). Muchos de los países de la región sufren recesiones, depresiones y crisis, algunas de las cuales han alcanzado niveles sin precedentes, que recuerdan a los de la Gran Depresión. ${ }^{1}$ Argentina, la alumna más destacada durante las primeras tres cuartas partes de la década, no sólo ha sufrido una crisis, sino que, por lo menos en algunos aspectos, ha sido denostada más allá de toda medida. ${ }^{2}$ Brasil, que también fue un alumno aventajado de la reforma, está pasando por una crisis en este preciso momento. ${ }^{3}$ Una estrategia de reforma que prometió crear una prosperidad sin pre- cedentes ha fracasado de una manera casi sin precedentes. Sus críticos habían dicho que si bien era posible que generara un crecimiento, les preocupaba que ese crecimiento no se distribuyera en forma amplia. Los resultados han sido peores de lo que muchos de sus críticos temían: para gran parte de la región, la reforma no sólo no ha generado crecimiento, sino que además, por lo menos en algunos lugares, ha contribuido a aumentar la desigualdad y la pobreza (cuadros 1 y 2).

Deseo, en esta exposición, explicar e interpretar esos fracasos y definir el marco de un nuevo programa de reforma económica para América Latina. Hace algunos años se hablaba de una "segunda generación de reformas". Se suponía que los países de la región estaban

GRAFICO 1
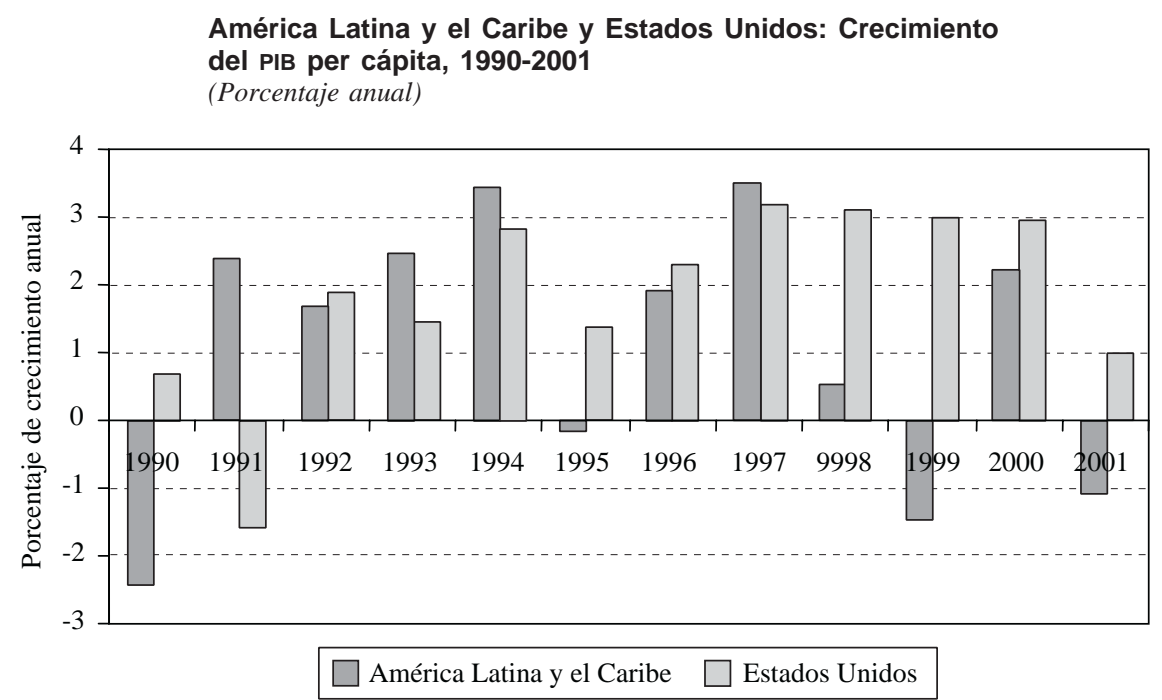

Fuente: Indicadores del desarrollo mundial (Banco Mundial, varios años).

\begin{abstract}
$\square$ Este artículo recoge una conferencia magistral con ocasión de la Segunda Cátedra Raúl Prebisch, dictada en la Comisión Económica para América Latina y el Caribe, en Santiago de Chile, el 26 de agosto de 2002. Deseo expresar mi agradecimiento a José Antonio Ocampo, a Dani Rodriky a los participantes de los seminarios celebrados en la CEPAL y en la Universidad Federal de Rio de Janeiro en los que se presentaron versiones anteriores de este trabajo. También le estoy muy agradecido a Sergio Godoy por su asistencia en la investigación. Agradezco profundamente el apoyo financiero prestado por las Fundaciones Ford, McArthur y Mott.

${ }^{1}$ Por ejemplo, en 2001, el crecimiento del PIB fue negativo en Argentina, Uruguay, México y Paraguay. La mayor disminución se
\end{abstract}

registró, por supuesto, en Argentina, donde la caída fue de 3,7\%, aunque en Uruguay fue de $3,1 \%$.

${ }^{2}$ No obstante, en mayo de 2003, al entrar esta publicación en prensa, hasta el Fondo Monetario Internacional (FMI) empezó a cambiar de opinión. Las predicciones más nefastas resultaron estar equivocadas; el país, si bien se enfrentaba a una profunda depresión, no sufrió una hiperinflación y, aun sin el apoyo del FMI — y a pesar de sus constantes críticas-, parece haberse estabilizado y ha comenzado su recuperación.

${ }^{3}$ La buena noticia es que ya en mayo de 2003 las perspectivas de Brasil parecían ser mucho más alentadoras. 
Población que vive con menos de 1,08 dólares por día (Paridad de poder adquisitivo de 1993)

\begin{tabular}{|c|c|c|c|c|c|}
\hline & 1987 & 1990 & 1993 & 1996 & 1998 \\
\hline África subsahariana & 46,6 & 47,7 & 49,7 & 48,5 & 46,3 \\
\hline Asia meridional & 44,9 & 44,0 & 42,4 & 42,3 & 40,0 \\
\hline América Latina & 15,3 & 16,8 & 15,3 & 15,6 & 15,6 \\
\hline Asia oriental & 26,6 & 27,6 & 25,2 & 14,9 & 15,3 \\
\hline Medio Oriente y Norte de África & 11,5 & 9,3 & 8,4 & 7,8 & 7,3 \\
\hline Europa oriental y Asia central & 0,2 & 1,6 & 4,0 & 5,1 & 5,1 \\
\hline Total & 28,7 & 29,3 & 28,5 & 24,9 & 24,3 \\
\hline
\end{tabular}

Fuente: Banco Mundial.

CUADRO 2

América Latina (13 países): Distribución del ingreso

(Relación entre la proporción que recibe el $20 \%$ más rico y la que recibe el $20 \%$ más pobre)

\begin{tabular}{lcccl}
\hline & 1990 & 1997 & 1999 & Diagnóstico \\
\hline Argentina & 13,5 & 16,4 & 16,5 & Deterioro \\
Bolivia & $21,4^{\mathrm{a}}$ & 34,6 & 48,1 & Deterioro \\
Brasil & 35,0 & $38,0^{\mathrm{b}}$ & 35,6 & Similar \\
Chile & 18,4 & $18,6^{\mathrm{c}}$ & $19,0^{\mathrm{d}}$ & Deterioro \\
Colombia & $35,2^{\mathrm{e}}$ & 24,1 & 25,6 & Mejoría \\
Costa Rica & 13,1 & 12,0 & 15,3 & Deterioro \\
Ecuador & 12,3 & 12,2 & 18,4 & Deterioro \\
El Salvador & $16,9^{\mathrm{f}}$ & 15,9 & 19,6 & Deterioro \\
Honduras & 30,7 & 23,7 & 26,5 & Mejoría \\
México & $16,9^{\mathrm{g}}$ & 17,4 & $18,5^{\mathrm{h}}$ & Deterioro \\
Panamá & $24,3^{\mathrm{i}}$ & 23,8 & 21,6 & Mejoría \\
Uruguay & 9,4 & 9,1 & 9,5 & Deterioro \\
Venezuela & 13,4 & 16,1 & 18,0 & Deterioro \\
& & & & \\
\hline
\end{tabular}

Fuente: CEPAL (2002c).

a 1989. b 1996. c 1996. d 2000. e 1994. f 1995. g 1989. h 2000. i 1991 .

digiriendo la primera generación de reformas, que éstas habían aportado los fundamentos a largo plazo del crecimiento económico, y que había llegado la hora de "afinar detalles" y abordar temas como la política de competencia, que no se habían tenido en cuenta en la primera generación de reformas. Me atrevería a sugerir que la primera generación de reformas padecía de fallas fundamentales. De lo que no cabe duda es de que no era completa. También resulta claro que no prestaba suficiente atención a aspectos como el ritmo y la secuencia de los cambios. Sin embargo, sus fallas eran más esenciales: no ponía el énfasis en lo que debía ponerlo; se basaba en un concepto erróneo de lo que hacía funcionar a una economía de mercado y en un análisis desacertado de la función que correspondía al gobierno.

Los fracasos de las denominadas reformas orientadas al mercado no implican por cierto que se deba volver al pasado, y para quienes están decididos a lograr un crecimiento democrático, equitativo y sostenible, esto representa un desafío. ¿Cuál es la alternativa? Es evidente que no existe una alternativa única; cada país debe elegir la opción que mejor se adapte a sus circunstancias y a su población. De hecho, la idea de promover una agenda única, sin adaptarla a las circunstancias de cada país, ha sido uno de los aspectos más criticados del Consenso de Washington, a mi juicio con razón. Sin embargo, hay algunas perspectivas generales, algunos temas comunes, que posiblemente estarán presentes en muchos países, y yo quisiera tratar de exponer esos temas comunes.

Para mí fue un privilegio especial dictar en memoria de Raúl Prebisch la conferencia aquí recogida, y fue la segunda ocasión en que pude hacerlo. ${ }^{4}$ A Prebisch también le inquietaba la grave situación de América Latina y las dificultades que la veía enfrentar. Le preocupaba, por ejemplo, la caída de los precios de los productos básicos. A los problemas que a él le causaban preocupación, hoy debemos agregar varios más.

\footnotetext{
${ }^{4}$ Véase Stiglitz (1998).
} 


\section{II}

\section{Los fracasos}

No es fácil desentrañar las dimensiones del fracaso. Actualmente ya se dispone de los datos sobre el total del primer decenio de la reforma. La tasa de crecimiento fue levemente superior a la mitad de la tasa registrada en las décadas de 1950, 1960 y 1970: para un conjunto de reformas que empezaron por criticar las políticas fallidas del pasado, éste es un resultado del que difícilmente es posible vanagloriarse (cuadro 3). Las cifras son aún más impactantes cuando se compara el desempeño de América Latina con el de otros países.

La teoría neoclásica tradicional pronostica una convergencia, es decir, que los países menos desarrollados crecerán más rápidamente (por trabajador) que los países desarrollados. Como muestra el cuadro 4 , hubo convergencia durante las décadas anteriores a la reforma, pero a partir de 1980 empezó a haber divergencia. El gráfico 1 muestra que incluso en los primeros años del decenio de 1990, cuando se proclamaba el éxito de las reformas, el ingreso per cápita en los Estados Unidos aumentó con mayor rapidez que en América Latina. Por supuesto que se podría haber dicho que era necesario "esperar a que las reformas surtieran efecto". Pero en ese caso las conclusiones son aún peores. Como puede verse claramente en el gráfico 1, el crecimiento se produjo en la primera mitad de ese decenio. En su segunda mitad, y especialmente a partir de 1997, hubo estancamiento, recesión y depresión. De hecho, el ingreso per cápita disminuyó en esos últimos cinco años, período que la CEPAL ha dado en llamar "la media década perdida". ${ }^{5}$

Los defensores de las reformas dicen: sí, el crecimiento durante los decenios de 1950, 1960 y 1970 fue vigoroso. Pero no fue sostenible. Sí, es verdad que

CUADRO 3

América Latina: Crecimiento medio anual

\begin{tabular}{lcccc}
\hline & $1960-1970$ & $1970-1980$ & $1980-1990$ & $1990-2001$ \\
\hline PIB & 5,32 & 5,86 & 1,18 & 3,05 \\
PIB per cápita & 2,54 & 3,36 & $-0,80$ & 1,39 \\
\hline
\end{tabular}

Fuente: Indicadores de desarrollo mundial (Banco Mundial, varios años).

\footnotetext{
${ }^{5}$ Véase Ocampo (2002).
}

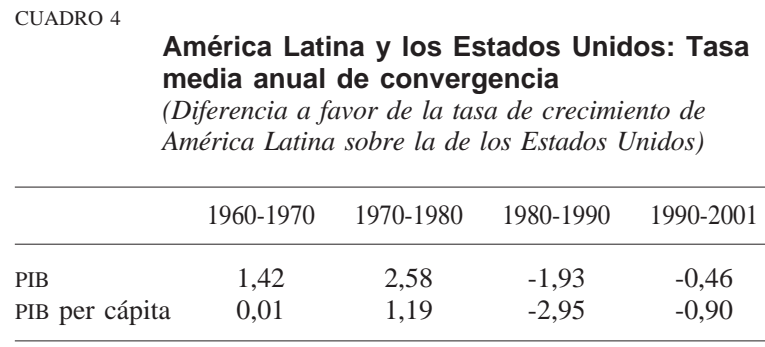

Fuente: Cálculos basados en datos de Indicadores de desarrollo mundial (Banco Mundial, varios años).

ese crecimiento no se mantuvo. Pero, ¿fueron fuerzas internas las que le pusieron fin, o fue un shock exógeno - el aumento repentino, inesperado y sin precedentes de las tasas de interés en los Estados Unidos- lo que determinó que la deuda de América Latina fuera insostenible? El hecho de que el aumento de las tasas de interés haya tenido por sí solo un efecto de tal magnitud refleja tanto el fracaso de los mercados internacionales de capital y del sistema financiero mundial como el de América Latina. Si los mercados de capital hubieran funcionado bien, los países industrializados avanzados habrían asumido el riesgo de las fluctuaciones de las tasas de interés. Uno hubiera esperado que los hábiles banqueros de esos países hubieran hecho un análisis de riesgo, que habría demostrado que si las tasas de interés subían, la deuda sería casi seguramente insostenible, y, por lo tanto, hubieran restringido los préstamos y por ende el grado de exposición de los países. Uno hubiera esperado, también, que la Junta de la Reserva Federal, tan altamente sofisticada, hubiera tenido en cuenta todos los efectos que se producirían si aumentaba las tasas de interés a niveles casi sin precedentes. Sin embargo, nada de esto ocurrió. En los contratos de préstamo se obligó a los países prestatarios pobres a asumir el riesgo; los bancos de Occidente no analizaron debidamente los riesgos, y no sólo porque estuvieran esperando a que los sacaran de apuros. (Es más, algunos de los banqueros occidentales que concedieron préstamos en forma irresponsable fueron ascendidos, en lugar de ser rebajados de categoría, porque habían demostrado una actitud dinámica en la concesión de préstamos, y eso fue lo que se premió). La Reserva Federal se concentró en la inflación, y cuando subió las tasas de interés, prestó poca atención a lo que pudiera pasar- 
le al sistema financiero de los Estados Unidos (de hecho, llevó a la quiebra a las instituciones de ahorro y crédito, que tenían activos de renta fija a largo plazo y pasivos a tasas de interés variables; a los contribuyentes estadounidenses les tomó casi una década pagar la cuenta por cientos de miles de millones de dólares); ${ }^{6}$ menos aún iba a pensar en las consecuencias que podrían derivarse para los deudores del exterior. Su argumento era muy sencillo: ¡no era parte de su mandato preocuparse por los efectos sobre el resto del mundo!

Sin embargo, las autoridades económicas de los países industrializados avanzados no quisieron asumir la plena responsabilidad de esos fracasos; era más fácil, y políticamente mucho más plausible, señalar las fallas de América Latina, y ésta, lamentablemente, era una presa fácil. Tenía empresas estatales ineficientes y corruptas, altas tasas de inflación, grandes déficit fiscales. No obstante, y a pesar de todos estos problemas, el crecimiento durante el régimen anterior a la reforma fue casi dos veces más rápido que el registrado durante el llamado régimen de reforma.

Claro está que no hay un método seguro de verificar las otras hipótesis: ¿fue un shock exógeno o el fracaso interno lo que trajo aparejado la década perdida? En realidad, ambos factores pueden haber influido, y no existe una forma sencilla de "repartir" la culpa con precisión. Sin embargo, en la próxima sección trataré de argumentar por qué, en mi opinión, la mayor parte de la culpa puede atribuirse al impacto causado en la región por el aumento de las tasas de interés en los Estados Unidos. Al igual que el resto del mundo, América Latina fue sacudida por el alza de los precios del petróleo en el decenio de 1970, pero acusó el golpe notablemente bien, mucho mejor que otras regiones. Sin embargo, podría decirse que lo hizo en forma no sostenible, valiéndose de la entrada de capitales (el reciclaje de los petrodólares). Parece improbable que un aumento súbito de la corrupción a fines de la década de 1970 y comienzos de la de 1980 haya sido la causa de la caída del continente. La explicación más sencilla y convincente es que fue la modificación inesperada de las tasas de interés lo que puso fin bruscamente al crecimiento. Aunque no hubiera habido corrupción y las empresas estatales hubiesen sido plenamente eficientes, es probable que la mayoría de los países de todos modos hubieran entrado en crisis.

No hay duda de que nadie desea volver al pasado. Sin embargo, la pregunta difícil de contestar es:

\footnotetext{
6 Véase un relato de este episodio en Kane (1989).
}

¿qué enseñanzas nos han dejado los éxitos, así como los fracasos, del pasado? Antes de pasar a ese punto, quisiera describir más ampliamente la índole de los fracasos del último decenio. Si bien las políticas del Consenso de Washington prometieron un crecimiento que no se concretó, el Consenso se refirió muy poco a las repercusiones que tendrían esas políticas en la inestabilidad. En lo que respecta a la pobreza, el Consenso se basó en las antiguas teorías de la filtración o goteo (trickle-down): las políticas económicas no estaban específicamente diseñadas para combatir el problema de la pobreza; lo que se presumía era que los prometidos beneficios del crecimiento llegarían de algún modo a los pobres - aunque para entonces ya estaba ampliamente demostrado que una marea que sube no eleva necesariamente todos los botes. ${ }^{7}$ Yo me atrevería a afirmar que no se pusieron todas las cartas sobre la mesa; como explicaré en la próxima sección, las políticas llevaron a más inestabilidad y más pobreza, lo que era previsible.

\section{Aumento de la inestabilidad: comparación de experiencias entre países desarrollados y en desarrollo}

El capitalismo ha estado siempre signado por enormes fluctuaciones. En todo caso, esas fluctuaciones se han agudizado en el mundo en desarrollo. ${ }^{8} \mathrm{El}$ contraste entre lo que ha estado sucediendo en los países en desarrollo y lo que ha ocurrido en los países desarrollados debería llamarnos la atención: en estos últimos, los períodos de recesión se han acortado, mientras que los de expansión se han hecho más largos, y los ciclos de descenso de la actividad económica podría decirse que son menos pronunciados. Actualmente tenemos los conocimientos que nos permiten gestionar mejor la economía, y es evidente que estamos aplicando esos conocimientos en los países más desarrollados. Sabemos cómo utilizar políticas monetarias y fiscales anticíclicas para sacar a un país de la recesión, y sabemos cómo diseñar estabilizadores automáticos para ayudar a proteger a la economía de los shocks que inevitablemente debe afrontar. Pero por alguna razón los países en desarrollo no

\footnotetext{
${ }^{7}$ En efecto, los datos correspondientes a los Estados Unidos indican que, durante los dos decenios que siguieron al año 1973, si bien el ingreso medio aumentó, la situación en la franja de menores ingresos fue empeorando y, según algunos estudios, se deterioró incluso la situación de la familia media. Véase Council of Economic Advisers (1997), cap. 5.

${ }^{8}$ De acuerdo con algunas estimaciones, 100 países han encarado crisis en los tres últimos decenios. Véase Caprio y Klingebiel (1999).
} 


\begin{tabular}{|c|c|c|}
\hline & $\begin{array}{c}\text { 1961-1980 } \\
\text { (Período anterior a la reforma) }\end{array}$ & $\begin{array}{l}\text { 1981-2000 } \\
\text { (Período de la reforma) }\end{array}$ \\
\hline \multicolumn{3}{|c|}{ Variabilidad (desviación estándar de la tasa de crecimiento) } \\
\hline Estados Unidos & 2,26 & 1,92 \\
\hline América Latina & 1,80 & 2,36 \\
\hline \multicolumn{3}{|c|}{ Número de años de crecimiento negativo } \\
\hline Estados Unidos & 3 & 2 \\
\hline América Latina & 0 & 4 \\
\hline \multicolumn{3}{|c|}{$\begin{array}{l}\text { Número de años de crecimiento inferior al } 90 \% \text { del } \\
\text { promedio de } 1961-2000\end{array}$} \\
\hline Estados Unidos & 8 & 3 \\
\hline América Latina & 6 & 12 \\
\hline
\end{tabular}

Fuente: Cálculos basados en datos extraídos de Indicadores de desarrollo mundial (Banco Mundial, varios años).

han disfrutado de los beneficios que se derivan de este mayor conocimiento, aunque debido a que sus redes de protección son más débiles se podría haber pensado que en su caso la estabilidad era aún más importante.

América Latina hizo más que su parte al contribuir a este sombrío panorama. El cuadro 5 muestra que la volatilidad, medida de varios modos diferentes, aumentó a partir de las reformas en América Latina, mientras que disminuyó en los Estados Unidos. En el período 1990-2001, en 25 países de la región el crecimiento fue negativo durante por lo menos un año, en 18 países durante un mínimo de dos años y en 12 países durante tres años o más.

\section{Aumento de la pobreza y la desigualdad}

Los críticos de la reforma no sólo señalan, y con razón, que el crecimiento no fue sostenible (o que por lo menos no fue sostenido), sino que expuso a los países a nuevas causas de volatilidad (véase más adelante el análisis de la manera en que las reformas aumentaron la inestabilidad). La volatilidad, a su vez, suele asociarse con un aumento de la pobreza: son los sectores más pobres de la sociedad los que normalmente sufren con mayor rigor las consecuencias del aumento del desempleo; son los trabajadores no calificados los que pasan a engrosar las filas de los desocupados y no tienen ahorros a los que recurrir. ${ }^{9}$ Los efectos de una contracción

\footnotetext{
9 Agénor (2002) llegó a la conclusión de que las tasas negativas de crecimiento tenían un efecto positivo en los índices de pobreza de una muestra de países menos desarrollados. Esto es así incluso en los países industrializados más avanzados. Véase Furman y Stiglitz (1998b).
}

incluso temporal de la actividad económica pueden ser duraderos, porque las personas que se quedan sin trabajo no pueden seguir costeando la educación de sus hijos. Una vez interrumpidos los estudios, existe una alta probabilidad de que no se retomen, aun cuando mejoren las cosas. De esa manera, la pobreza se transmite de una generación a la siguiente.

Por añadidura, algunas de las reformas son en sí mismas la causa directa del aumento de la pobreza: obligar a los agricultores pobres a competir con la agricultura subsidiada estadounidense disminuyó los ingresos de algunos de los más pobres de la región; y la aplicación de regímenes de restricción monetaria dificultó la creación de nuevos puestos de trabajo que proporcionaran otras fuentes de empleo. Además, el legado de una educación deficiente para los más desfavorecidos hizo aún más difícil la redistribución de la mano de obra, especialmente cuando la liberalización se llevó a cabo con rapidez.

En la región en su conjunto, la proporción de personas que viven en la pobreza creció de 15,3\% en 1987 a 15,6\% en 1998 (cuadro 1). Si bien no se dispone aún de datos más recientes, es casi seguro que, debido a la crisis que afecta a tantos países, la pobreza haya aumentado significativamente desde 1998.

\section{Desigualdad}

Incluso en países que han exhibido crecimiento, como México, una parte desmesurada de los beneficios ha ido a parar a manos del $30 \%$, ó $10 \%$, de la población de mayores ingresos, y muchas de las personas más pobres, las de la franja del $30 \%$ de menores ingresos, están en 
peor situación que antes. ${ }^{10}$ También en este caso podemos entender por qué: esto se debe en parte a que la población de menores ingresos es la que sufre los efectos de las fluctuaciones económicas inherentes a la estrategia de reforma orientada al mercado. ${ }^{11}$ Esto es consecuencia, en parte, de la estructura general de la reforma, que dio lugar a la adopción de medidas que tuvieron por efecto eliminar puestos de trabajo o rebajar los salarios de los trabajadores no calificados, como paso previo a la aplicación de otras medidas que podrían haber propiciado la creación de empleos y el aumento de su productividad; o, peor aún, que se tradujo en la adopción de medidas que provocaron la eliminación de puestos de trabajo, acompañadas de medidas que reprimieron la creación de empleos.

El resultado de las políticas que supuestamente iban a mejorar el funcionamiento de los mercados fue que, por lo menos en algunos aspectos críticos, los mercados funcionaron peor. El desempleo creció casi tres puntos porcentuales, ${ }^{12}$ y las cifras habrían sido peores si una parte mayor de la fuerza laboral no se hubiera incorporado al sector informal de la economía, un sector en el que normalmente los trabajadores gozan de menor protección y en que el acceso al capital - y por ende el potencial de crecimiento futuro- es más reducido. ${ }^{13}$ En el cuadro 2 se puede ver cómo aumentó la desigualdad a lo largo del decenio en varios países de América Latina.

\section{Las múltiples dimensiones de la pobreza: los indicadores de desarrollo humano}

Los fracasos en las dimensiones estrechas del crecimiento económico van de la mano de los fracasos en las dimensiones más amplias del bienestar humano, que abarcan no solamente la pobreza, sino también la educación y la salud. El gráfico 2 muestra el deslucido desempeño de América Latina en lo que respecta al índice de desarrollo humano del Programa de las Naciones Unidas para el Desarrollo (PNUD). Las reformas no han contribuido en absoluto a reducir la brecha que existe entre el índice de desarrollo humano de la región y el de los países industrializados avanzados.

\footnotetext{
${ }^{10}$ Véase, por ejemplo, Bouillon, Legovini y Lustig (2001).

${ }^{11}$ Por cierto, algunos de los más pobres - los agricultores de subsistencia aislados de la economía de mercado- fueron los menos afectados por las reformas. Si se excluyen del análisis, las consecuencias pueden tener un aspecto aún más sombrío.

12 CEPAL (2002a).

13 Las dimensiones del cambio son alarmantes. Según la CEPAL (2002b), más del 70\% de los empleos generados en la región durante la década de 1990 correspondió al sector informal.
}

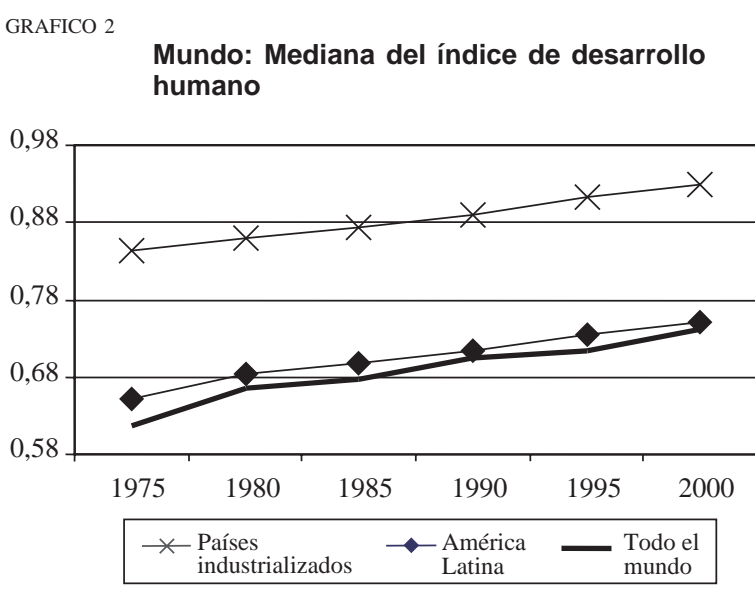

Fuente: Informe sobre desarrollo humano (PNUD), varios años).

\section{Las múltiples dimensiones de la pobreza: la inseguridad}

El Banco Mundial, en su informe del decenio para la erradicación de la pobreza (Banco Mundial, 2000), señala como dimensiones clave de ella no solamente la falta de ingresos, sino también la inseguridad y la falta de voz; las denominadas estrategias de reforma han agudizado estos dos problemas. Si bien la agenda de reforma no produjo un crecimiento vigoroso, sí contribuyó a aumentar la sensación de inseguridad. Mientras los efectos de la creciente volatilidad económica recaían con mayor rigor sobre los pobres, se acentuaba en ellos la sensación de inseguridad económica. Como si esto fuera poco, las reformas contribuían casi deliberadamente a acrecentar aún más dicha inseguridad. Uno de los elementos del programa de reforma, denominado "aumento de la flexibilidad del mercado laboral", consistió en reducir las medidas de protección del empleo, dando a las empresas mayores facilidades para despedir a los trabajadores y rebajar los salarios. Sin embargo, y como ya se señaló, aunque se suponía que las reformas iban a mejorar el funcionamiento de los mercados laborales - es decir, iban a reducir el desempleo-, lo sorprendente es que, en los hechos, el porcentaje de desempleados aumentó. Durante el decenio, una creciente proporción de la fuerza laboral se desplazó hacia el sector informal, donde no existen las medidas de protección que proporciona el sector formal.

La inseguridad tiene, por supuesto, otras dimensiones. La seguridad personal se ha visto afectada por el aumento de la delincuencia y la violencia en muchos países (cuadro 6), aunque la situación en materia de protección de la salud es, en general, positiva (cuadro 7). 


\begin{tabular}{|c|c|c|c|}
\hline & $\begin{array}{c}\text { Fines del decenio } \\
\text { de } 1970\end{array}$ & $\begin{array}{c}\text { Fines del decenio } \\
\text { de } 1980\end{array}$ & $\begin{array}{c}\text { Mediados del decenio } \\
\text { de } 1990\end{array}$ \\
\hline Argentina & 3,9 & 4,8 & 4,7 \\
\hline Brasil & 11,5 & 19,7 & 23,0 \\
\hline Chile & 2,6 & 3,0 & 3,0 \\
\hline Colombia & 20,5 & 89,5 & 61,6 \\
\hline Costa Rica & 5,7 & 5,6 & 5,4 \\
\hline Ecuador & 6,4 & 10,3 & 15,3 \\
\hline El Salvador & nd & 138,2 & 55,6 \\
\hline México & 18,2 & 17,8 & 15,9 \\
\hline Nicaragua & nd & 18,3 & 8,4 \\
\hline Panamá & 2,1 & 10,9 & 10,9 \\
\hline Paraguay & 5,1 & 4,0 & 12,3 \\
\hline Perú & 2,4 & 11,5 & nd \\
\hline Trinidad y Tabago & 2,1 & 12,6 & 12,1 \\
\hline Uruguay & 2,6 & 4,4 & 4,4 \\
\hline Venezuela & 11,7 & 15,2 & 16,0 \\
\hline
\end{tabular}

Fuente: Para la primera y segunda columnas, OPS (1996). Para la tercera columna, Krug, comp. (2002).

CUADRO 7

América Latina y el Caribe: Indicadores de salud

\begin{tabular}{lrrr}
\hline & 1970 & 1982 & 1993 \\
\hline Esperanza de vida al nacer (en años de vida) & 61 & 65 & 68 \\
Mortalidad infantil (por cada 1.000 nacidos vivos) & 84 & 71 & 70 \\
Mortalidad de menores de 5 años (por 1.000) & 123 & 38 & 32 \\
\hline
\end{tabular}

Fuente: Base de datos del Sistema de gestión y análisis de datos estadísticos (SIMA) del Banco Mundial.

\section{Las múltiples dimensiones de la pobreza: la falta de voz}

Si bien la mayor parte de este artículo se centra en cuestiones que se definen más estrictamente como temas económicos, quisiera mencionar brevemente la tercera dimensión de la pobreza, que es la falta de voz. Uno de los presuntos grandes logros de la reforma latinoamericana fue el restablecimiento de la democracia. Ese fue un auténtico logro. No obstante, la democracia en el verdadero sentido de la palabra es algo más que la mera democracia electoral. La verdadera democracia supone la participación en la toma de decisiones del país, y entre las decisiones más importantes están las que repercuten en mayor medida en la vida de la gente: las decisiones económicas. Sin embargo, en el marco de las llamadas reformas orientadas al mercado, mucha gente del mundo en desarrollo considera que ha sido estafada. Es posible que pueda votar, pero se le ha privado del derecho a ser oída en otros aspectos esenciales. Después de venderle la democracia, le dicen que las decisiones fundamentales, relativas a la política macroeconómica (y especialmente la monetaria), son demasiado importantes como para dejarlas libradas a los procesos políticos democráticos. No se puede confiar en el pueblo - le dicen-, porque es muy probable que lo engañen los dirigentes populistas. Los bancos centrales deben ser independientes; en la mayoría de los casos, han sido no sólo independientes, sino carentes de representatividad: sólo se han expresado allí las perspectivas y los intereses financieros.

Lo que es aún peor, se le ha dicho a los países que deben abrir sus mercados al capital especulativo de corto plazo. Eso, se argumenta, les dará disciplina. Estas afirmaciones logran apenas ocultar una desconfianza en los procesos democráticos: los propios procesos electorales no ofrecen evidentemente la disciplina necesaria para tomar las decisiones económicas correctas. Poco se menciona que los especuladores de corto plazo tienen perspectivas e intereses muy diferentes a los de la gente del país: los países se han sometido a la disciplina de intereses caprichosos que sólo piensan en el 
muy corto plazo, sin preocuparse en lo más mínimo por otros valores sociales como la equidad $u$ otros aspectos con repercusiones a más largo plazo, como el medio ambiente. ${ }^{14}$ En algunos casos, parece que se oyeran con más claridad las voces de Wall Street que las voces de quienes viven en las favelas y los barrios. ${ }^{15}$

\section{Algunos hechos positivos}

Quizás he presentado hasta aquí un panorama demasiado lúgubre. Existen, sin embargo, algunos rayos de luz, ensombrecidos a veces por las estadísticas agregadas. En algunos países ha habido mejoras notables en la educación: en Brasil, por ejemplo, la tasa de matrícula en la enseñanza primaria aumentó de $80 \%$ a $97 \%$. En muchos países, como ya hemos señalado, se han registrado progresos importantes en el sector de la salud. En varios países ha habido cambios institucionales extraordinarios, que van desde el control de los gastos del Estado hasta la creación de bancos centrales con credibilidad, el establecimiento de mercados de capitales que funcionan bien, el aumento de la eficiencia y la rendición de cuentas en el sector público, y medidas de descentralización que han ampliado la capacidad de respuesta del gobierno a las preocupaciones de los ciudadanos. ${ }^{16}$ Es evidente que estas reformas institucionales no han generado todavía el crecimiento prometido, pero es posible que promuevan un mayor crecimiento en el futuro. Es interesante observar, sin embargo, que incluso los que creen en las bondades de las reformas han comenzado a moderar su optimismo: aducen que las economías saldrán de la recesión, que se reanudará el crecimiento, pero pocos de ellos se atreven a expresar siquiera la esperanza de que se pueda recuperar el tipo de crecimiento vigoroso que caracterizó los decenios de 1950 y 1960. La promesa es que se cerrará la brecha entre América Latina y los países industrializados adelantados, pero a un ritmo tan lento que será apenas perceptible y en formas que dejan planteado el interrogante de si en realidad existe alguna esperanza de lograr progresos rápidos, ya sea en cuanto a mejorar la estabilidad o reducir la pobreza.

\section{III}

\section{Interpretación de las experiencias}

Es prácticamente indiscutible que el desempeño del decenio de 1990 no sólo ha sido, en casi todas sus dimensiones, muy inferior al prometido, sino que ha sido desastroso, desde casi cualquier punto de vista. ${ }^{17} \mathrm{Sin}$ embargo, el problema de juzgar las políticas del Consenso de Washington radica en parte en el conocido dilema del escenario contrafáctico. ¿Qué hubiera pasado de no haber sido por las reformas del Consenso de Washington? ¿El crecimiento hubiera sido aún más decepcionante?

La controversia sobre la interpretación de la historia de América Latina gira en torno a tres preguntas centrales: ¿cómo se explica la década perdida de 1980 , esa caída aparentemente rápida después de un crecimiento vigoroso?; ¿cómo se explica el auge de princi-

\footnotetext{
14 También hay razones para creer que, por lo menos con frecuencia, la comprensión de los conceptos económicos básicos que tienen estos especuladores suele ser limitada: les interesan más los factores que rigen la dinámica de los precios en el corto plazo, que las fuerzas que impulsan la dinámica del crecimiento a largo plazo. ${ }^{15}$ Las consecuencias para los procesos democráticos han sido particularmente notorias en el Brasil.
}

pios del decenio de 1990?; y ¿cómo se explica la caída igualmente repentina a fines de él, al cabo de un período tan corto? Nos encontramos en medio de un gran drama teatral: ¿resurgirá en el próximo acto un crecimiento vigoroso?, ¿veremos desatarse nuevas crisis?, ¿o en el próximo acto veremos más de lo mismo: estancamiento y poco crecimiento? El problema estriba

\footnotetext{
${ }^{16}$ A veces, estas reformas han tenido resultados opuestos. En algunos países, como Colombia, la descentralización hizo aún más difícil la tarea de controlar los presupuestos generales.

${ }^{17}$ Los defensores de las reformas se apresuraron a cantar victoria cuando vieron aumentar el crecimiento a principios del decenio de 1990. Dieron por sentado que ello se debía a las reformas, y prestaron poca atención al hecho de que aun en ese momento el desempeño no era particularmente impactante desde el punto de vista histórico. Pero ahora que las cifras muestran un panorama más lúgubre, dicen que es demasiado pronto para sacar conclusiones y que es una comparación injusta ya que los últimos años se han caracterizado por una desaceleración económica a nivel mundial. No hay duda de que es necesario ejercer cautela a la hora de emitir juicios, como lo han demostrado ampliamente las precoces afirmaciones sobre el éxito de las reformas. Sin embargo, una de las críticas que se han hecho a las reformas es que han contribuido a la inestabilidad económica mundial y además han expuesto a los países en desarrollo a mayores riesgos (véase a continuación).
} 
en que es poco probable que el próximo acto se ajuste al libreto original. La mayoría de los países están tan preocupados por la forma en que se ha desarrollado la obra, que es probable que decidan cambiar el libreto. Por lo tanto, e independientemente de lo que suceda, entraremos en otra ronda de controversias difíciles de resolver: si las economías se recuperan, ¿será gracias a los cambios, o a pesar de ellos?

Para poder interpretar las experiencias, tenemos que analizar lo que ocurrió desde una perspectiva tanto microeconómica como macroeconómica. En la próxima sección trataré de demostrar en mayor detalle que es posible detectar un nexo causal entre determinadas políticas del Consenso de Washington y los fracasos. En esta sección haré un análisis más general.

\section{La interpretación de la década perdida}

Por débil que haya sido, el crecimiento del decenio de 1990 fue, en cifras totales, superior al de la década perdida de 1980, en la que la deuda pendiente aplastó a las economías de la región. Ese período de estancamiento terminó, pero yo me atrevería a sugerir que el fin de la década perdida estuvo más relacionado con la solución del problema de la deuda pendiente que con las estrategias de reforma, del mismo modo que el estancamiento de la región comenzó a raíz del peso agobiante de la deuda. Si analizamos el decenio de 1990 desde esa perspectiva, nuestra visión del crecimiento limitado en dicho decenio será aún más negativa. Y ello debido a que no es extraño que, cuando una economía atraviesa un período de recesión o estancamiento, haya un período de "puesta al día", en el cual se aprovechan oportunidades perdidas y se hacen inversiones para incorporar adelantos tecnológicos. Esta interpretación parece particularmente plausible cuando se observa que el crecimiento más vigoroso ocurrió efectivamente en la primera mitad de la década. Por lo tanto, según esta perspectiva, deberíamos examinar conjuntamente los decenios de 1980 y 1990, en cuyo caso el crecimiento registrado en el marco de la reforma es aún peor, ya que no alcanza a la mitad de lo que fue en las décadas anteriores a la reforma y, en términos per cápita, es apenas positivo (cuadro 8).

Cabe reconocer, para ser justos, que existe otra interpretación según la cual lo sucedido en la década de 1980 fue la consecuencia inevitable de las políticas fallidas de las décadas anteriores, en cuyo caso el estancamiento de esa década debería atribuirse más precisamente a ese período anterior. Sin embargo, aun en ese caso, el crecimiento anterior a la reforma parece
CUADRO 8

$\begin{aligned} & \text { A. Visión de la reforma como un período de recuperación } \\ & \text { de las consecuencias de políticas insostenibles } \\ & \text { (Tasa media de crecimiento anual) }\end{aligned}$
PIB
PIB per cápita
(T,59\% $1-1980$
$2,15 \%$

B. Visión de la década perdida como parte de una estrategia fallida de sustitución de las importaciones

(Tasa media de crecimiento anual)

\begin{tabular}{lcc}
\hline & PIB & PIB per cápita \\
\hline $1961-1990$ & $4,10 \%$ & $1,69 \%$ \\
$1991-2001$ & $3,05 \%$ & $1,39 \%$ \\
\hline
\end{tabular}

Fuente: Cálculos basados en datos de Indicadores de desarrollo mundial (Banco Mundial, varios años).

más vigoroso que el ocurrido en el marco de la reforma.

Hay varias razones que me llevan a inclinarme decididamente a favor de la primera interpretación. En primer lugar, era de esperar que una perturbación macroeconómica de la magnitud que tuvo el aumento de las tasas de interés aplicables a estos países tan endeudados fuera suficiente para precipitar por sí sola una crisis - aunque la "microeconomía" funcionara perfectamente- y que esa crisis provocara a su vez una caída en picada del crecimiento del PIB. En segundo lugar, y relacionado con lo anterior, las dificultades microeconómicas no suelen generar crisis, sino que se limitan a reducir los niveles de ingresos. Se podría aducir, por supuesto, que los préstamos se contrajeron para enjugar déficit presupuestarios originados por empresas estatales ineficientes; sin embargo, la mayoría de los observadores parece opinar que el aumento de la deuda externa se debió principalmente a fuerzas macroeconómicas (el reciclaje de los petrodólares). Hagamos el siguiente ejercicio mental: ¿qué habría sucedido si las empresas hubieran sido plenamente eficientes, pero, al observar el alto rendimiento (esperado) de sus actividades de inversión - alto, por lo menos, en relación con las tasas de interés que se estaban cobrando-, hubieran contraído empréstitos para financiar inversiones, de modo que la diferencia entre el ahorro interno y la inversión hubiera sido idéntica a la observada? Es casi seguro que los países habrían entrado en crisis cuando los Estados Unidos subieron sus tasas de interés a niveles sin precedentes. En síntesis, la crisis se habría producido igual, con independencia de que el 
endeudamiento externo se debiera a la contracción del ahorro o al aumento de la inversión, y de la mayor o menor eficiencia de las empresas estatales. En ese sentido, no se podría haber culpado únicamente a la ineficiencia de esas empresas. ${ }^{18}$

Hay un ejercicio mental que discurre en sentido contrario al anterior, y que puede plantearse en los siguientes términos: supongamos que los Estados Unidos no hubieran subido las tasas de interés. ¿El endeudamiento excesivo de las empresas estatales ineficientes habría provocado a la larga el colapso del sistema, aunque los Estados Unidos no hubieran aumentado las tasas de interés? Si ése fuera el caso, se podría aducir que el aumento de las tasas de interés sólo influyó en el aspecto cronológico de la crisis, no en el hecho de que ocurriera o no. Sin embargo, si se acepta esta interpretación, es preciso creer que los gobiernos no vieron lo que se les venía encima. De acuerdo con esta interpretación, los problemas de los países habrían ido agravándose lentamente, de manera que los gobiernos habrían podido tomar medidas antes de que la crisis llegara a su desenlace. ${ }^{19}$

Uno de los motivos por los cuales es tan difícil interpretar el decenio de 1980 es la dificultad que existe para analizar la década de 1970. En esta última se registró un crecimiento relativamente intenso, en parte propiciado por enormes corrientes de capital que, según algunos, no eran sostenibles, pero que, en todo caso, a partir del fuerte aumento de las tasas de interés en los Estados Unidos, no se mantuvieron. Asimismo, fue sacudida por fluctuaciones demasiado profundas de los precios del petróleo, que frenaron el crecimiento en gran parte del resto del mundo. Por lo tanto, si bien la productividad total de los factores en América Latina (como se mide tradicionalmente) fue aparentemente baja en la década de $1970,{ }^{20}$ dicha década fue testigo

\footnotetext{
${ }^{18}$ Existen, por cierto, situaciones hipotéticas en las cuales América Latina se hubiera podido salvar de la crisis: se podrían haber creado instituciones (como en Asia oriental) para estimular el ahorro privado, y de ese modo hubiera habido poca necesidad de recurrir a la inversión extranjera. Sin embargo, estas no son las hipótesis "contrafácticas" en las que se basa la mayoría de los análisis de políticas.

${ }^{19}$ Existen, claro está, teorías de los procesos políticos que postulan que muchas veces los grandes cambios sólo pueden lograrse como resultado de una crisis.

${ }^{20}$ En la década de 1970 no sólo hubo convergencia entre América Latina y los Estados Unidos, sino que al parecer hubo convergencia incluso en cuanto a la eficiencia (productividad total de los factores). A pesar de los numerosos problemas metodológicos y de medición que notoriamente inciden en esas mediciones, uno de los estudios más respetados sobre los Estados Unidos demostró que en ese decenio la productividad total de los factores había disminuido
}

de importantes descensos en el crecimiento de la productividad total de los factores en todo el mundo, aun sin corrupción y sin la ineficiencia asociada a las empresas estatales. ${ }^{21}$

\section{Interpretación de la desaceleración de fines del decenio de 1990}

El crecimiento de principios de ese decenio no se mantuvo. Los críticos pueden afirmar con acierto que no era sostenible. Los primeros años de la década se caracterizaron por la entrada de enormes corrientes de capital. En cierto sentido, los países gastaban más de lo que ganaban. Esto podría no haber tenido mayores consecuencias si las corrientes de capital se hubieran destinado a inversiones a largo plazo de tipo totalmente nuevo que ampliaran la capacidad de producción de la economía, con un rendimiento superior a las tasas de interés que debían pagar los países, y si una parte tan importante de las corrientes de capital no hubiera sido de corto plazo. ${ }^{22}$

De hecho, en un determinado momento, el FMI, sin prestar mucha atención a los riesgos que entrañaban las corrientes de capital de corto plazo, parecía creer que, en la medida en que el endeudamiento externo no fuera generado por el desorden fiscal en el sector público (gasto público superior a los ingresos del Estado), los déficit de la cuenta corriente serían sostenibles. Incluso en el caso de que la deuda se hubiera contraído para financiar el consumo de los hogares, los prestadores no habrían otorgado los préstamos si los hogares no hubieran tenido capacidad de pago. Los préstamos internacionales cumplieron una función importante al contribuir a moderar el consumo en el correr del tiempo. ${ }^{23} \mathrm{Sin}$ embargo, las corrientes de capital son en realidad sumamente volátiles: someten a los mercados de capital a

(a una tasa anual media de $0,25 \%$ ), mientras que otro estudio señaló aumentos considerables en la productividad total de los factores (a una tasa anual media de $0,75 \%$ ). Con respecto a los Estados Unidos véase Dougherty y Jorgenson (1997), y para América Latina véase De Gregorio y Lee (1999).

${ }^{21}$ En los Estados Unidos, por ejemplo, si bien la productividad de la mano de obra había aumentado aproximadamente un 2,9\% durante los decenios de 1950 y 1960, a partir del año 1973 la productividad creció a una tasa de alrededor del 1,1\%; gran parte de esa caída se asocia a una desaceleración en el ritmo de la productividad total de los factores (Baily, Stiglitz y Tyson, 1995).

${ }^{22}$ En Ricardo Ffrench-Davis (2003a) puede verse un análisis de la inestabilidad macroeconómica en América Latina desde este punto de vista. En Damill y Frenkel (2003), por ejemplo, figura un estudio sobre Argentina.

23 Esta opinión se expone, por ejemplo, en Prasad, Rogoff y otros (2003). 
excesos de optimismo y pesimismo irracionales. Además, en el caso de los países en desarrollo, generalmente los grandes déficit de la cuenta corriente, sea cual sea su origen, no son sostenibles, y los ajustes que es preciso hacer para eliminarlos -modificaciones drásticas de los tipos de cambio o disminuciones importantes del ingreso, o ambas cosas a la vez - reducen las importaciones. En muchos países de América Latina han sucedido ambas cosas. ${ }^{24}$ Cuando entran grandes corrientes de capital de corto plazo, los cambios de actitud pueden reflejarse rápidamente en una negativa a renovar préstamos o en un retiro de capital de cartera. (En el caso de una liberalización total del mercado de capital, aunque no haya grandes corrientes de capital de corto plazo, puede haber una fuga de capitales de inversionistas nacionales).

Sin embargo, la entrada de capitales no impulsó un resurgimiento de la inversión real. Según ciertos cálculos, gran parte de ese capital se utilizó simplemente para financiar un aumento del consumo. ${ }^{25}$ La entrada de capitales fue en parte resultado de la privatización, de la venta de los bienes de los países a extranje$\operatorname{ros}^{26}$

\section{Los efectos de una contabilidad inadecuada: la proyección de una falsa imagen de éxito en los primeros años de la reforma}

Las prácticas contables contribuyeron a dar una falsa impresión de éxito. Los países debían haber centrado la atención en el ingreso nacional neto, pensando en las posibilidades de bienestar futuro de los ciudadanos y tomando en cuenta la depreciación de los recursos físicos del país y el agotamiento de sus recursos natu-

\footnotetext{
${ }^{24}$ En trabajos recientes sobre macroeconomía, que hacen hincapié en el papel de las variables balance y flujo de efectivo, se explica por qué los descensos importantes del tipo de cambio pueden, en el corto plazo, estar asociados a un debilitamiento de la macroeconomía. Véase, por ejemplo, Greenwald (1999), Greenwald y Stiglitz (1993) y Furman y Stiglitz (1998a).

${ }^{25}$ Por ejemplo, entre 1990 y 1996, mientras que la inversión aumentó en 166.400 millones de dólares, el ahorro sólo se incrementó en 132.400 millones de dólares. Si la tasa de ahorro se hubiera mantenido constante al nivel de 1990 (como porcentaje del PIB), el ahorro hubiera aumentado casi en el mismo monto que la inversión (la diferencia habría sido sólo de 300 millones de dólares), lo que significa que América Latina no hubiera tenido que pedir préstamos en ese período. Es fácil imaginar, por ende, que la casi totalidad de los 34.000 millones de dólares de las corrientes de capital debe de haber ido a parar al consumo, habida cuenta del crecimiento que se registró en éste.

${ }^{26}$ Esto no mejoró la capacidad de producción de la economía, salvo en la medida en que la gestión extranjera aumentó la eficiencia con la que se emplearon los activos.
}

rales, la degradación del medio ambiente, la venta de los activos nacionales en el exterior y el agravamiento de la sensación de inseguridad y vulnerabilidad económicas.

Hay una serie de pasos que deben darse para pasar del PIB al ingreso nacional neto: si no perdemos de vista la diferencia entre las dos medidas, podemos entender mejor por qué el PIB dio una falsa impresión de éxito en el período inicial de la reforma.

En primer lugar, existen varias diferencias entre el producto interno bruto y el producto interno neto. Toda empresa sabe que debe tomar en cuenta la depreciación de su capital. Sin embargo, si un país vende sus bosques de madera dura, podrá contabilizar lo que reciba a cambio como "ingresos", pero habrá reducido el patrimonio del país. ${ }^{27}$ Un método de contabilidad correcto habría diferenciado entre la venta de un activo y lo que es realmente ingreso. Por lo tanto, el producto nacional o interno neto habría deducido esa pérdida del valor del bosque.

De manera similar, el producto interno bruto y el producto interno neto se basan en los bienes que se producen en el país, y no en el bienestar de sus ciudadanos. Es una medida útil del nivel de actividad económica dentro de un país, pero no lo es del grado de bienestar de las personas que viven en él. Lo importante para los ciudadanos de un país es el ingreso nacional neto. Si un país vende sus activos en el extranjero, y como resultado de la venta se lanza a consumir en forma desenfrenada, sus ciudadanos se volverán más pobres. Sus perspectivas futuras habrán empeorado. Por consiguiente, la venta de empresas estatales a extranjeros en el marco de las privatizaciones debe contabilizarse como una disminución del patrimonio de los ciudadanos, que debe deducirse del ingreso nacional neto; si la entrada de fondos generada por las privatizaciones se destina a realizar inversiones de tipo totalmente nuevo, la pérdida registrada en una cuenta se compensa con la ganancia contabilizada en la otra. En cambio, si esto no sucede - y por lo menos hasta cierto punto no sucedió-, significa que el país se ha empobrecido. Por ende, una contabilidad correcta habría

\footnotetext{
27 Del mismo modo, puede resultar muy engañoso no tomar en cuenta la depreciación de los bienes de capital públicos. Un país que recorta sus gastos para mantener los activos públicos puede mostrar un déficit menor, y un inversionista financiero corto de miras podría pensar, por ello, que las perspectivas futuras de la economía son mejores. Sin embargo, las pérdidas derivadas del deterioro de la infraestructura pública pueden más que compensar los aparentes beneficios de la reducción del déficit, sin que ello se refleje en los estados contables.
} 
mostrado un panorama menos halagüeño en los primeros años de la década de 1990.

Más allá de las privatizaciones realizadas mediante la venta a extranjeros, gran parte del capital que entró era de corto plazo, es decir, el tipo de dinero que puede entrar y salir de un día para otro, y no la clase de dinero con la cual se podrían construir fábricas y crear empleos. Una contabilidad apropiada habría tomado en cuenta este pasivo, compensado por la inversión que milagrosamente hubiera podido generar. También en este caso, al aumentar el pasivo sin un aumento correspondiente de los activos productivos, el país se empobrece. Una buena contabilidad lo habría reflejado.

Es indudable que, aun si las entradas de capital de corto plazo no contribuyeron a aumentar el patrimonio, tuvieron un efecto positivo de corto plazo sobre la demanda agregada (que, dependiendo de las circunstancias del país, puede haber sido amortiguado por políticas monetarias y fiscales restrictivas). En la medida en que existían recursos subutilizados, el aumento de la demanda agregada estimuló el crecimiento. Debido a que el producto aumentaba más rápidamente que los insumos, parecía que la "reforma" había puesto en marcha una nueva era de incrementos de la productividad. Sin embargo, y en su mayor parte, los aumentos registrados en la productividad fueron simplemente los aumentos normales que se observan cuando una economía se recupera de una recesión, y América Latina, a principios del decenio de 1990, se estaba recuperando de un período de diez años de desaceleración de la actividad económica.

Un buen sistema contable hubiera ido incluso más allá. Habría advertido que el capital de corto plazo es muy volátil; que cuando el país, por las vicisitudes del mercado, decide retirarse de éste o exigir una tasa de interés más alta, puede caer en una crisis y verse obligado a pedir un préstamo al FMI o a recortar gastos en formas que reducen los ingresos futuros. Un buen sistema de contabilidad habría exigido que se guardaran reservas - una cifra que se descontaría del ingreso nacional neto- en previsión de ese costo futuro. Si una compañía de seguros emprende una actividad riesgosa - como la de vender seguros - debe guardar dinero, mantener un fondo de reserva, para reflejar el costo previsto de esa actividad. ${ }^{28}$

\footnotetext{
${ }^{28}$ Irónicamente, el FMI pensó que la reformas que había impuesto en América Latina habían reducido la vulnerabilidad de ésta a las crisis y que, en ese sentido, el verdadero bienestar de los países era aún mejor que lo que sugerían las cifras del PIB. De acuerdo con $s u$ análisis, la causa principal de la vulnerabilidad eran las políticas monetarias no restrictivas, que conducían a la inflación y el despil-
}

El capital de corto plazo planteaba otro problema: la tasa de interés que devengaba era variable. Las tasas de interés que podían exigir los prestamistas podían elevarse en forma drástica, aunque los países no hicieran nada indebido. Ésta, como ya hemos argumentado, fue la causa principal de la crisis de principios del decenio de 1980: la Reserva Federal de los Estados Unidos aumentó enormemente y en forma repentina las tasas de interés. Los niveles de la deuda, hasta ese momento sostenibles, se volvieron súbitamente insostenibles. A fines de la década de 1990, no sólo se acentuó la percepción de los mercados con respecto a la deuda de los mercados emergentes (causada, en parte, por la crisis financiera mundial), sino también la "aversión al riesgo" del mercado. Como consecuencia, la prima de riesgo que exigían los inversionistas aumentó fuertemente, compensando con creces las tasas de interés algo menores de los Estados Unidos y Europa. Nuevamente, los niveles de deuda que podrían haber sido sostenibles se volvieron repentinamente insostenibles. ${ }^{29}$

Por lo tanto, el sistema contable — que centraba la atención en el PIB - no dio una visión exacta de lo que estaba sucediendo. Si bien las cifras citadas, el producto interno bruto, sugerían que el desempeño de las economías latinoamericanas a principios de la década de 1990 era realmente admirable, un mejor sistema contable habría presentado un panorama mucho más sombrío.

\section{Si tan sólo no hubiera ocurrido la crisis finan- ciera mundial...}

Los defensores de la reforma dicen: si no hubiera ocurrido la crisis financiera mundial, el crecimiento se habría mantenido. Pero esta afirmación es errónea en dos aspectos. En gran medida, la crisis financiera mundial fue en sí misma un producto del movimiento mundial de reforma, incluida la liberalización del mercado de capitales. ¿Qué cambió en Asia oriental, la región del mundo que durante tres décadas no sólo

\footnotetext{
farro fiscal. En estas dimensiones, el desempeño de la mayoría de los países fue ampliamente superior a lo que había sido anteriormente. Sin embargo, la liberalización de los mercados de capital había introducido una causa aún más importante de vulnerabilidad. Se puede ver un análisis de las causas de la vulnerabilidad en Furman y Stiglitz (1998a) y Easterly y otros (2000), y en las referencias allí citadas.

${ }^{29}$ Damill y Frenkel (2003) estiman que la mayor parte del aumento de la deuda de Argentina en el período anterior a la crisis final de 2001 puede atribuirse a esas tasas de interés más altas.
} 
tuvo el crecimiento más rápido sino también la mayor estabilidad, en la que dos de los países que entraron en crisis tuvieron solamente un año de coyuntura desfavorable, y otros dos no experimentaron ni siquiera un año de contracción, lo cual mostraba un desempeño más positivo que el de cualquiera de los países de la Organización de Cooperación y Desarrollo Económicos (OCDE)? El factor preponderante, diría yo, no fue el aumento de la corrupción y la falta de transparencia, como nos podría haber hecho creer el FMI. Por el contrario, al menos en varios de los países afectados, la corrupción estaba disminuyendo y la transparencia iba en aumento. ${ }^{30} \mathrm{El}$ problema radicaba más bien en la liberalización prematura y excesivamente rápida de los mercados financieros y de capital, y la falta de marcos regulatorios adecuados. ${ }^{31}$ En lugar de preguntar cuál era el marco regulatorio apropiado, se centró la atención únicamente en la desregulación, con consecuencias desastrosas.

En América Latina las reformas han contribuido en gran medida a resolver algunos de los problemas del pasado. Se han atenuado los déficit fiscales, aunque no se les ha eliminado, y se han hecho grandes progresos en cuanto a reducir la inflación. Los defensores de las reformas adujeron que los datos de principios del decenio de 1990 confirmaban que habían sido un acierto. Retrospectivamente, vemos lo engañosas que fueron esas conclusiones. Parte de ese éxito aparente se debió a la expansión de la demanda agregada, gracias a que finalmente se había encarado el problema de la deuda pendiente, al aumento repentino de las entradas de capital, y al incremento de las exportaciones como resultado de una vigorosa coyuntura económica en los Estados Unidos durante los llamados "formidables años noventa". Este crecimiento de la demanda agregada determinó que se utilizaran recursos que habían permanecido ociosos durante mucho tiempo. Fue más bien una expansión convencional del lado de la demanda, y no un crecimiento del lado de la oferta como recalcaban los reformistas. Hubo algunos elementos importantes del lado de la oferta, pero eran muy diferentes a los que señalaban los defensores de la reforma. Parte de ese éxito aparente fue la consecuencia natural del proceso de puesta al día posterior a la década perdida de 1980. Otra parte fue resultado del crecimiento no sostenido, o insostenible, del capital extranjero.

En algunos de esos mismos "éxitos" estaba la simiente de los problemas de fines del decenio de 1990 y los primeros años del nuevo milenio. ${ }^{32}$ Las reformas habían expuesto a los países de América Latina a nuevas fuentes de riesgo. Los sistemas contables no solamente no habían tenido en cuenta esos riesgos, sino que además, en muchos otros aspectos, habían proporcionado mediciones que exageraban el éxito alcanzado.

\section{IV}

\section{Explicación de los fracasos}

En esta sección me propongo examinar los fracasos con mayor detenimiento. En la sección anterior sostuve que los fenómenos macroeconómicos, que se originan fuera de la región, tienen mucho que ver con su volatilidad. Me refiero en particular a las altas tasas de interés de principios del decenio de 1980 y al cambio de orientación del capital de corto plazo a mediados de la década de 1990. Aquí quisiera mostrar de qué manera las reformas del Consenso de Washington, a pesar de las buenas intenciones que puedan haber teni-

\footnotetext{
30 Véase, por ejemplo, Furman y Stiglitz (1998a).

31 Véase, por ejemplo, Rodrik y Velasco (1999). Estudios más recientes del FMi han confirmado que la liberalización del mercado de capitales se asocia en muchos países en desarrollo a una mayor volatilidad, pero no necesariamente a un crecimiento mayor. Véase, por ejemplo, Prasad, Rogoff y otros (2003).
}

do, aumentaron la vulnerabilidad de los países de la región a esos shocks externos y contribuyeron en otros sentidos a los fracasos de los últimos años. Centraré la atención en tres fallas críticas de las reformas:

- Las reformas, incluidas las diversas formas de liberalización, aumentaron la exposición de los países al riesgo, sin acrecentar su capacidad de hacer frente a ese riesgo.

- Las reformas macroeconómicas no eran equilibradas, porque asignaban demasiada importancia a la lucha contra la inflación y no atendían lo suficien-

\footnotetext{
32 En Stiglitz (2003) sugiero que la coyuntura económica desfavorable que comenzó en los Estados Unidos en marzo de 2001 también puede explicarse en gran medida como una consecuencia del fracaso de las políticas del decenio de 1990.
} 
te a la lucha contra el desempleo y la promoción del crecimiento.

- Las reformas impulsaron la privatización y el fortalecimiento del sector privado, pero dieron muy poca importancia al mejoramiento del sector público; no mantuvieron el equilibrio adecuado entre el Estado y el mercado.

\section{Aumento de la exposición al riesgo}

Todas las reformas del Consenso de Washington - la liberalización del comercio, del mercado de capitales y del sector financiero- expusieron a los países a un mayor riesgo. La experiencia de Chile con la desregulación del sector financiero, así como la propia experiencia de los Estados Unidos a principios del decenio de 1980, tendrían que haber enviado una señal de alerta más que suficiente con respecto a los riesgos. ${ }^{33}$ Sin embargo, al parecer casi sin pensar en estos riesgos, se impulsó el programa de liberalización.

En 1995, mientras yo estaba en la Casa Blanca, observé muy atentamente la caída del valor del dólar con respecto al yen, de 106 a 80 yen por dólar aproximadamente. Esta disminución de $25 \%$ en el valor del dólar no reflejaba un súbito empeoramiento de las perspectivas económicas de los Estados Unidos ni un mejoramiento repentino de las de Japón, del mismo modo que el fortalecimiento igualmente marcado del dólar que se produjo a continuación, cuando su valor pasó de 80 a 130 yen por dólar, no reflejó un cambio similar en las perspectivas económicas de ambos países. Como lo ha dicho hasta el propio Alan Greenspan, uno de los más fervientes defensores del capitalismo estadounidense, los mercados muestran una exuberancia excesiva e irracional y, como podría haber afirmado él mismo, a veces también hacen gala de un pesimismo excesivo e irracional. ${ }^{34}$ Economías poderosas como la de los Estados Unidos pueden soportar estas vicisitudes, pero esa volatilidad ejerce una presión enorme en economías abiertas, pequeñas y pobres. A pesar de ello, las denominadas reformas han expuesto a estos países a esas vicisitudes del mercado de una manera sin preceden-

\footnotetext{
${ }^{33}$ Actualmente existe una amplia bibliografía en la que se analizan los riesgos de la desregulación del sector financiero y el diseño de los regímenes regulatorios apropiados. Véase, por ejemplo, Honohan y Stiglitz (2001), Stiglitz (2001a), y Helmann, Murdoch y Stiglitz (2000).

${ }^{34}$ Por supuesto que lo que hacía Greenspan era sólo tomar nota de un aspecto importante que estaban investigando otros economistas, como Robert Shiller (2000), cuyo trabajo refuta de manera convincente la hipótesis de los mercados eficientes.
}

tes, tanto a través del comercio como de las corrientes de capital, y antes de que pudieran consolidar sus redes de protección.

\section{Liberalización de los mercados de capitales}

La liberalización de los mercados de capitales fue la reforma que provocó los efectos más adversos. ${ }^{35}$ Los modelos económicos simples postulaban que los países en desarrollo eran iguales a los países desarrollados, salvo en cuanto a que tenían pocos recursos y sobre todo menos capital. Esta perspectiva del desarrollo indujo a los países a creer que si lograban obtener más capital, podrían crecer con mayor rapidez. Si no podían generar ahorro internamente (como habían podido hacerlo con tanto éxito los países de Asia oriental, con una fuerte intervención del gobierno), entonces tendrían que recurrir al exterior. El argumento era sencillo: siempre que el rendimiento superara la tasa de interés que se pagaba, la inversión era buena para la economía; el préstamo podría pagarse fácilmente, y el remanente de la ganancia enriquecería al país. Tampoco importaba mucho si el capital era de corto o de largo plazo.

La escasez de capital significaba que el rendimiento del capital debía ser mayor en los países en desarrollo que en los países desarrollados, y al liberalizar los mercados de capitales habría un flujo constante de capital de los países más desarrollados a los de menos desarrollo. Ambos grupos saldrían beneficiados: los países desarrollados debido al mayor rendimiento del capital, y los países en menos desarrollo merced a la entrada de un mayor volumen de capital, que redundaría en salarios más altos y mayor productividad. Los partidarios de la liberalización de los mercados de capital adujeron incluso que habría una mayor estabilidad; en períodos de contracción, los países en desarrollo podrían pedir préstamos en el exterior para fortalecer sus economías.

Estos argumentos de los defensores de la liberalización de los mercados de capital eran sorprendentes por la ingenuidad de la teoría en que se basaban — prácticamente se desestimaba la bibliografía cada vez más abundante que hacía hincapié en las consecuencias de las imperfecciones de la información- y por su grado de desconocimiento de la realidad de los mercados de capital. Las corrientes de capital de corto plazo son sumamente volátiles; en lugar de amortiguar la volatilidad

\footnotetext{
${ }^{35}$ Los riesgos vinculados a la liberalización de los mercados de capitales se describen más ampliamente en Stiglitz (2000a y 2002a).
} 
económica, como vaticinaban sus defensores, contribuyeron en gran medida a producirla, e incluso cuando no eran los factores causantes del problema, acrecentaron la magnitud de las fluctuaciones. Estas corrientes de capital son, en particular, altamente procíclicas. Entran en un país cuando todo marcha bien, y salen cuando las cosas andan mal. Los banqueros son amigos en tiempos de bonanza: están dispuestos a prestar cuando los países no necesitan dinero. Y los países cometieron la insensatez de dejarse seducir por el atractivo de los préstamos. Pero cuando las cosas se ponen difíciles, los bancos exigen la devolución de su dinero.

América Latina ciertamente ya había visto todo esto, y con creces, 20 años antes, cuando, al entrar en recesión, los prestamistas no sólo se habían negado a concederle créditos, sino que le habían pedido la devolución de su dinero. Además, si bien se suponía que los acreedores multilaterales tenían el deber de ayudar a los países en épocas de necesidad, con frecuencia sólo servían para agudizar los problemas. Generalmente, en esos períodos de crisis, cuando los países están en una situación desesperada, lo único que se plantea es cuánto dinero devolverán a los Estados Unidos y a los demás países industrializados avanzados. Hay una corriente neta de capital que sale del país, y no que entra. Las conversaciones entre el FMI y Argentina no versaban acerca de los préstamos adicionales que se otorgarían, sino sobre cuánto de lo que debía ese país se tendría que devolver al año siguiente.

La volatilidad y el carácter procíclico de estos fondos han tenido además otras consecuencias. Los prestatarios no tomaron plenamente en cuenta los factores externos, especialmente los que se asocian a ese tipo de préstamos cuando las cosas andan mal, como sí se hizo en Asia oriental y otros países. No fueron solamente los prestatarios los que debieron asumir los costos, especialmente en el marco de las medidas propuestas por el FMI para responder a las crisis. Las altas tasas de interés pueden llevar a la quiebra incluso a los que sólo se han endeudado modestamente; la contracción fiscal y monetaria empuja al desempleo a millones de trabajadores. Es indudable que el FMI reconoce indirectamente que hubo una falla en el mercado, porque habla de contagio. Pero llama la atención que no haya respondido en la forma en que lo hacen normalmente los economistas cuando detectan la influencia de factores externos. Generalmente los economistas preguntamos si existe una intervención en el mercado que pueda corregir ese factor externo, como por ejemplo un impuesto sobre la actividad que genera dicho factor. $\mathrm{Si}$ los préstamos de corto plazo generan el riesgo de que actúe un factor externo, entonces es preciso gravar con un impuesto los préstamos de corto plazo. Las enfermedades contagiosas no se combaten simplemente construyendo mejores hospitales para quienes tienen la mala suerte de contraer la enfermedad, sino que es necesario estudiar cómo se propaga la enfermedad, subsidiar las vacunas, inclusive dictar normas para imponer la vacunación obligatoria y prohibir cierto tipo de actividades riesgosas. Sin embargo, el Fondo, en las políticas que se adoptaron en forma tan generalizada en América Latina, que promovían activamente la liberalización de los mercados de capitales, pareció estimular las mismas fuerzas que originaban el problema.

La disposición a contraer préstamos con una financiación de corto plazo fue particularmente descaminada. No se pueden construir fábricas con dinero que puede entrar o salir del país de un día para otro. La prudencia aconseja hoy en día a los países mantener reservas por un monto equivalente al de sus deudas de corto plazo en moneda extranjera. Esto significa que si un país contrae un préstamo por 100 millones de dólares, debe tener en reserva ese mismo monto - es decir, 100 millones de dólares de dinero público- que podría haberse utilizado para construir escuelas o carreteras. Esas reservas le generan una ganancia, pero la situación del país en su conjunto es peor, porque las reservas se mantienen normalmente en letras del Tesoro a corto plazo en dólares que hoy en día tienen, digamos, una rentabilidad de menos del $2 \%$, mientras que el país tiene que pagar tal vez el $18 \%$ o más al banco estadounidense. El costo neto para el país es de 16 millones de dólares, una transferencia neta del país en desarrollo pobre a los Estados Unidos. Esto puede contribuir al crecimiento de los Estados Unidos, pero es difícil imaginar que pueda favorecer el crecimiento de los países en desarrollo pobres. Esta situación que acabo de describir demuestra que el costo total de los préstamos no corre por cuenta del prestatario, y esto es también una falla del mercado.

No hay duda de que cuando entra capital en un país es fácil ver los beneficios: ellos fueron evidentes en América Latina a principios de la década de 1990. Pero también es obvio que las ventajas que obtienen los países no compensan las pérdidas que sufren en caso de crisis, esas crisis que ocurren con tanta frecuencia y regularidad y cuyos efectos negativos han sido particularmente profundos en América Latina. Por otra parte, el costo de las quiebras ha ido subiendo con el tiempo, no sólo porque ha aumentado el número de acreedores y eso hace más difícil solucionar los problemas en forma ordenada, sino también porque la combinación de 
acreedores nacionales y extranjeros, incluidas las instituciones financieras nacionales, y la coexistencia de deudas en dólares y en moneda nacional no sólo plantean cuestiones de difícil solución en lo que respecta al trato equitativo, sino que además hacen recaer los efectos adversos de las crisis en la viabilidad de las instituciones financieras nacionales, socavando aún más la economía.

\section{Estabilidad macroeconómica}

Las economías de la región han experimentado una gran inestabilidad a nivel macroeconómico. Como ya se señaló, el FMI y los neoliberales daban a esos fenómenos una interpretación muy particular, según la cual la causa primaria de los trastornos macroeconómicos era el despilfarro del gobierno, su intervención en los mercados y la laxitud de la política monetaria. Esta interpretación de la inestabilidad macroeconómica hizo caso omiso de doscientos años de historia del capitalismo: mucho antes de que los gobiernos asumieran las funciones que cumplen hoy en día, las economías de mercado ya habían sufrido los efectos devastadores de la volatilidad, el auge repentino y las caídas vertiginosas. Por lo menos en los países industrializados más avanzados, la evolución ha sido clara: la intervención del gobierno ha ayudado a estabilizar la economía. Más recientemente, las crisis de Asia oriental han demostrado que las causas de los trastornos pueden ser otras. Con anterioridad a las crisis, estos países tenían bajos niveles de inflación y gozaban de superávit presupuestarios. Si en algo fallaron los gobiernos, fue en que no reglamentaron lo suficiente el sector financiero, en que hicieron muy poco para moderar el aumento repentino de las corrientes de capital que se produjo a raíz de la liberalización del mercado de capital, y en que tomaron muy pocas medidas para limitar el alcance de la especulación desestabilizadora.

Existe, en este sentido, una notable semejanza entre las crisis de América Latina y las de Asia oriental, y es que la inestabilidad a nivel macroeconómico fue causada en gran parte por los problemas vinculados al endeudamiento externo y a la liberalización de los mercados de capital. Los países latinoamericanos se vieron obligados nuevamente a soportar la mayor parte del peso de las alzas de las tasas de interés, iniciadas en otras partes del mundo, y a afrontar las consecuencias de la inestabilidad de las corrientes de capital.

$\mathrm{Si}$ bien las reformas (incluidas las del comercio, que se analizarán más adelante) expusieron a los paí- ses a nuevas fuentes de enormes riesgos, también influyeron en la forma en que la economía respondió a esos shocks. Las reformas sustituyeron los estabilizadores automáticos por desestabilizadores automáticos. En lugar de ser anticíclica, la política fiscal de América Latina en su conjunto ha sido procíclica. Y no porque los economistas latinoamericanos hayan omitido leer los textos de macroeconomía de los últimos 70 años, en los que se hace hincapié en la importancia de una política fiscal anticíclica, sino más bien en parte porque el FMI, del que tantos países latinoamericanos se han vuelto dependientes en materia de asesoramiento y dinero, ha alentado, algunas veces con insistencia, la aplicación de políticas procíclicas. Debido a la poca profundidad de los mercados nacionales de capital, las corrientes procíclicas de capital privado, el vívido recuerdo de la inflación galopante de épocas anteriores, la insistencia del FMI en que se hicieran recortes presupuestarios, y la tendencia de las instituciones multilaterales, sobre todo del FMI, a conceder con frecuencia préstamos procíclicos, los países aparentemente no tuvieron más alternativa que aplicar una política fiscal procíclica. No obstante, como sugeriré más adelante, sí existe una alternativa.

En tanto que los estabilizadores fiscales automáticos vinculados a la política fiscal han sido reemplazados por un desestabilizador automático, la política monetaria también se ha convertido en una fuente de inestabilidad, y es probable que esta situación empeore en el futuro. Se ha alentado a los países a confiar cada vez más en los requisitos de suficiencia de capital y a no caer en la indulgencia, que, según se alega, sólo posterga el día del juicio final, empeorando las cosas cuando finalmente afloran los problemas. En Asia oriental, sin embargo, vimos las nefastas consecuencias de esta política: cuando una economía entra en una coyuntura desfavorable, aumentan los casos de incumplimiento, empeoran los balances bancarios y, como resultado, surge rápidamente la necesidad de pedir préstamos. (La alternativa, una nueva inyección de capital, no suele ser viable en medio de una contracción económica). ${ }^{36}$ Pero a medida que obtienen préstamos, más empresas caen en situación de incumplimiento, o por lo menos se ven obligadas a disminuir sus inversiones y su producción, y en consecuencia la contracción económica se agudiza. En algunos casos, a la larga ni

\footnotetext{
$36 \mathrm{O}$ el costo para los propietarios actuales —medido en función del debilitamiento de sus derechos de propiedad- es suficientemente alto como para que consideren atractiva esa medida.
} 
siquiera mejoran los balances de los bancos, o mejoran muy poco; y hasta pueden empeorar. ${ }^{37}$

Si bien, como ya se ha dicho, las reformas expusieron a los países de la región a más shocks y socavaron su capacidad de hacerles frente automáticamente, las políticas promovidas por el Consenso de Washington empeoraron aún más las cosas: una preocupación casi exclusiva por los problemas del pasado, por el déficit presupuestario y la inflación, determinó que, cuando los países vieron disminuir su recaudación fiscal como consecuencia de la caída de sus ingresos, o aumentar sus gastos a medida que subían las tasas de interés sobre los préstamos que habían contratado, se les alentó a que recortaran los gastos y aumentaran los impuestos, y estas políticas fiscales discrecionales procíclicas exacerbaron aún más la recesión en un país tras otro.

En algunos casos, los países estaban de manos atadas, ya que tenían dificultades para conseguir fondos. Sin embargo, hasta a los países que podían acceder a fondos - un país como Chile, que había creado un fondo de estabilización, o países ricos en recursos como el Ecuador y Bolivia, que podían pedir préstamos a cuenta de ventas futuras- se los alentaba a no aplicar políticas fiscales anticíclicas. En algunos casos, los métodos contables engañosos que utilizaban el FMI y otros analistas financieros contribuyeron a agravar los problemas.

Estamos cada vez más conscientes de las limitaciones de nuestros sistemas de contabilidad, tanto en el sector público como en el privado. La información errónea conduce a decisiones erróneas. Los métodos contables deficientes utilizados por las empresas estadounidenses contribuyeron a inflar los precios de manera excesiva, lo que a su vez contribuyó a un exceso de inversión en sectores como el de las telecomunicaciones. Las deficiencias de los sistemas de contabilidad públicos son aún más notorias, y entre ellas cabe mencionar, por ejemplo, la falta de separación entre los gastos de capital y los gastos corrientes, y el no tomar en cuenta el agotamiento de los recursos naturales o la degradación del medio ambiente, como señalamos en nuestro análisis anterior. No obstante, los buenos macroeconomistas deberían entender las limitaciones de los métodos contables. Si, por ejemplo, se privatiza el sistema de seguridad social, y los fondos que

\footnotetext{
${ }^{37}$ Este es otro ejemplo de algo que se enseña en las primeras semanas de los cursos elementales de economía, la "falacia de composición". Lo que podría ser razonable si hubiese un único banco con problemas, no tiene sentido cuando el problema es sistémico.
}

anteriormente fluían hacia las arcas del Estado comienzan repentinamente a verterse en cuentas de inversión privada, el aumento del déficit del sector público no necesariamente acentuará los desequilibrios macroeconómicos, y es posible que ni siquiera represente un problema para el gobierno que financia dichos déficit. ${ }^{38}$

Los sistemas de contabilidad engañosos no sólo contribuyeron a un exceso de austeridad, a una política fiscal excesivamente restrictiva en medio de una coyuntura desfavorable, sino que además dieron lugar a que se hiciera una inversión insuficiente en infraestructura (los gastos se sumaron a los déficit, y los beneficios sencillamente no se registraron) y contribuyeron a aumentar la inestabilidad económica. Se alentaba a los países a que contrajeran préstamos en dólares porque la tasa de interés en esa moneda era más baja que en la moneda local. ${ }^{39} \mathrm{El}$ presupuesto tenía un aspecto más agradable. Claro está que, en la medida en que los mercados funcionen bien, la diferencia entre la tasa de interés en dólares y la tasa de interés en la moneda local refleja las expectativas sobre la evolución del tipo de cambio. ${ }^{40}$ Sin embargo, los gobiernos (y el sector privado, tanto prestadores como prestatarios) subestimaron sistemáticamente el riesgo inherente a las fluctuaciones del tipo de cambio, y sus consecuencias. En un país tras otro, lo que comenzó siendo un nivel moderado de endeudamiento externo, terminó convirtiéndose en una carga insostenible como resultado de las depreciaciones.

\section{La liberalización del comercio}

Si bien la apertura de los mercados de capital y las políticas macroeconómicas procíclicas fueron las principales causantes de las tribulaciones económicas de la región, la liberalización del comercio también tuvo su participación. Se abrieron los mercados, con la consiguiente eliminación de empleos, en la ingenua creen-

\footnotetext{
${ }^{38}$ Que esto suceda o no depende en parte de la racionalidad del mercado. Si las obligaciones no financiadas se consideraron verdaderos compromisos del gobierno, una reforma que permitiera financiar una fracción mayor de esas obligaciones debería mejorar la visión que tiene el mercado de la situación financiera del Estado. Nótese que si el gobierno toma prestado de los fondos privados, entonces, en lo que respecta al flujo de fondos, la situación es idéntica a la que imperaba antes de la privatización.

${ }^{39}$ El FMI alentó activamente a algunos países a contraer préstamos en dólares.

40 Otras reformas pueden también haber contribuido a la inestabilidad: la sustitución de cuotas por aranceles, independientemente de sus virtudes en términos de transparencia, puede exponer a un país a una mayor volatilidad. Véase Dasgupta y Stiglitz (1988).
} 
cia de que seguía vigente la ley de Say, según la cual la oferta crea su propia demanda.

Cuando esto no sucedió, como era de esperar, se culpó nuevamente a los países: el problema se debía a la excesiva rigidez del mercado laboral. Los salarios bajaron aún más, empobreciendo todavía más a los pobres. Si los salarios eran lo suficientemente bajos, las empresas podrían considerar rentable contratar a más trabajadores. De esta manera se hizo oídos sordos tanto a la teoría como a las pruebas empíricas. Uno de los principales avances de la teoría económica de los últimos 30 años ha sido la teoría de los salarios de eficiencia, según la cual la rebaja de los salarios puede hacer disminuir la productividad, de tal manera que la demanda de mano de obra aumente poco y posiblemente hasta disminuya. En trabajos empíricos realizados en los Estados Unidos se ha demostrado que el salario mínimo ha tenido pocos efectos adversos, o ninguno, en el empleo (Card y Krueger, 1995). En la mayoría de los países de la región, el sector informal, en el que no inciden las rigideces convencionales, es enorme. Si los postulados económicos del FMI fueran correctos, ese sector podría absorber por sí solo toda la mano de obra; se comprimiría el sector de los salarios rígidos; habría diferencias entre los salarios y algunas ineficiencias derivadas de ellas, pero seguiría habiendo pleno empleo en la economía. Las pruebas en contra de esta hipótesis son contundentes. En efecto, en Argentina, a medida que el sector informal iba creciendo hasta abarcar quizás el 50\% de la economía, siguió aumentando el desempleo, que se ha mantenido en niveles de dos dígitos desde 1995.

La culpa no es tanto de la rigidez de los salarios ${ }^{41}$ sino de las políticas del FMI, que con frecuencia han minado la capacidad de las economías de crear nuevos empleos, al imponerles tasas de interés más altas, entre otras medidas. Como resultado, la liberalización del comercio ha fomentado la movilidad de los trabajadores, que no han pasado de empleos de baja productividad a empleos de alta productividad, sino de empleos de baja productividad al desempleo.

Es evidente que el injusto sistema de comercio internacional no ha hecho más que empeorar las cosas. ¿Cómo podrían competir los agricultores pobres de

\footnotetext{
${ }^{41}$ En efecto, en Easterly, Islam y Stiglitz (2000) se muestra que el aumento de la flexibilidad laboral no está relacionado con una mayor estabilidad económica.
}

Chiapas con el maíz altamente subsidiado de los Estados Unidos? Al bajar los precios del maíz como consecuencia de la liberalización del comercio, también disminuyeron los ingresos de los agricultores pobres de México que dependían de las ventas de maíz. Los obreros de la industria del norte de México estaban en una situación más ventajosa, debido al aumento de la demanda de exportaciones a América del Norte, pero quienes pagaron el precio fueron, entre otros, los sectores de la franja inferior de la distribución del ingreso.

\section{Un papel equilibrado para el Estado}

Las políticas del Consenso de Washington perseguían casi un único objetivo: reducir el papel del Estado. Incluso la estabilización macroeconómica no apuntaba a dar al gobierno un papel más activo en la estabilización de la economía, sino a restringir su papel mediante el recorte de gastos. El énfasis puesto en el impuesto al valor agregado (IVA) — sin exceptuar los alimentos y ni siquiera los medicamentos- como fuente de ingresos tributarios también limitaba la función del gobierno en la redistribución.

Los mercados privados no desempeñaron el papel estabilizador que les atribuían los fundamentalistas del mercado. ¿Por qué habríamos de sorprendernos? Las fuerzas del mercado por sí solas nunca han garantizado automáticamente la estabilidad económica. Lo único que sorprende es que estos resultados hayan sido al parecer tan inesperados para los defensores del Consenso de Washington.

Sin embargo, ni siquiera los partidarios de los mercados privados creyeron en algún momento que esas políticas podrían resolver todos los problemas ya que, por ejemplo, no garantizaban una distribución equitativa del ingreso. Uno de los problemas fundamentales de las políticas del Consenso de Washington era su visión estrecha de las cosas: se centraban en la eficiencia económica, con la esperanza de que los demás problemas sociales se resolvieran en algún otro contexto. Fracasaron en la búsqueda de sus objetivos económicos estrechos. No obstante, incluso al fracasar en su restringida misión, exacerbaron otros problemas sociales más amplios. Aunque las políticas del Consenso de Washington hubieran logrado promover el crecimiento y la estabilidad, se podría haber exigido que se reformaran las reformas. Sin embargo, la suma de los fracasos convierte a la reforma de las reformas en una imperiosa necesidad. 


\section{Los principios de la reforma}

En esta sección deseo formular algunos de los principios generales en los que debería inspirarse cualquier agenda de reforma — es decir, de reforma de las reformas.

\section{Objetivos}

La reforma debe tener objetivos claros y apuntar a metas mucho más ambiciosas que un simple aumento del PIB. Actualmente se reconoce cada vez más que los objetivos del Consenso de Washington eran demasiado estrechos, o, más precisamente, descaminados en lo que respecta a sus prioridades. Tendrían que haberse centrado en el desarrollo democrático, equitativo y sostenible.

\section{Los fines por oposición a los medios}

Los medios no deben nunca confundirse con los fines. Muchas veces el Consenso de Washington trató a la privatización, la liberalización y la estabilización como fines en sí mismos, y no como medios de alcanzar objetivos más amplios. Se suponía que debían generar ingresos más altos y un crecimiento más rápido. Es evidente que la apertura de los mercados de capitales no ha logrado ese objetivo; por el contrario, sólo ha traído aparejada una mayor inestabilidad. La liberalización del sector financiero con frecuencia también ha generado inestabilidad, tras lo cual el gobierno ha tenido que emprender costosos rescates. La privatización de los monopolios, sin reglamentación, puede provocar un alza de los precios a medida que los dueños privados aprenden a explotar mejor el poder del mercado. La región lleva la marca de privatizaciones fracasadas, y de privatizaciones que no han podido cumplir sus promesas en materia de bancos, caminos, agua, telecomunicaciones, seguridad social. Es posible que si las privatizaciones se hubieran realizado de manera diferente, con mayor cuidado, los resultados habrían sido mejores. ${ }^{42}$ Pero ése es sólo un aspecto del problema: estas reformas se encararon casi como si fueran fines en sí mismas. A veces parecía imperar la creencia de

\footnotetext{
42 Más adelante se analiza con cierto detenimiento el tema de la privatización y la liberalización.
}

que no importaba cómo se hicieran las reformas: lo único importante era llevarlas a cabo.

El énfasis puesto en la inflación refleja no sólo una visión demasiado estrecha - como hemos visto, la estabilidad macroeconómica implica algo más que reducir la tasa de inflación-, sino también una confusión de los fines con los medios. El razonamiento es que deberíamos preocuparnos por la inflación porque puede impedir el crecimiento económico, ${ }^{43}$ y existen algunas pruebas de que las tasas muy altas de inflación lo hacen. ${ }^{44}$ Sin embargo, las medidas adoptadas para limitar la inflación pueden de por sí tener un efecto negativo sobre el crecimiento, en cuyo caso debemos establecer un equilibrio entre ambas cosas. ${ }^{45} \mathrm{Hemos}$ visto cómo, en la práctica, el énfasis excesivo en la inflación ha reprimido el crecimiento. ${ }^{46}$ En efecto, Akerlof, Dickens y Perry (1996) han argumentado que el nivel óptimo de inflación es estrictamente mayor que cero, y

\footnotetext{
43 También preocupa que la inflación pueda afectar negativamente a los pobres; sin embargo, los efectos adversos del desempleo son aún mayores. Muchos de los estudios empíricos que sugieren que "la inflación es el impuesto más cruel para los pobres" confunden los efectos de la inflación en sí misma con la perturbación que la causa. Por ejemplo, la fuerte oscilación de los precios del petróleo en el decenio de 1970 provocó un aumento de la inflación además de repercutir negativamente en la situación de los pobres.

${ }^{44}$ Esas pruebas deben interpretarse con cautela, ya que normalmente, cuando las tasas de inflación son muy altas, existen algunas perturbaciones subyacentes que dan lugar a un desequilibrio macroeconómico, y un fracaso del gobierno en resolver esos problemas. Por lo tanto, suele haber un problema de identificación: jel bajo nivel de crecimiento es el resultado de la alta tasa de inflación o de los factores que la causan?

${ }^{45}$ Hay por cierto algunos modelos que sugieren que no existe tal compensación (trade-off), que existe una curva de Phillips vertical aumentada, pero también hay otros que afirman que no existe en absoluto una curva de Phillips. En todo caso, la experiencia reciente, en los Estados Unidos y otros países, es congruente con la hipótesis de que existe una curva de Phillips no vertical en el corto plazo, incluso aunque a la larga la economía pague el precio de los niveles muy bajos de desempleo. De todos modos, yo creo que las pruebas a favor de la existencia de una curva de Phillips vertical son lo suficientemente débiles como para que los países, por un tiempo prudencial, no basen sus políticas en la hipótesis de que es vertical. En términos más generales, si existe una tasa de desempleo que no acelera la inflación (NAIRU), pero también hay incertidumbre en cuanto a su nivel, las conclusiones en materia de políticas son muy similares.

${ }^{46}$ Efectivamente, en el caso de Rusia puede haber sido uno de los factores que contribuyeron a que aumentara el trueque, lo que de por sí genera ineficiencias en la asignación de los mercados, de igual gravedad que las que se asocian a una inflación alta.
} 
en el Japón y otros países hemos visto los efectos adversos de la deflación. ${ }^{47}$ Los que se preocupan únicamente por la inflación han argumentado que una vez que ésta comienza no se puede detener, y que los costos de revertirla son altos; sin embargo, ninguna de estas dos aseveraciones soporta un escrutinio empírico. ${ }^{48}$

No obstante, el énfasis excesivo en la austeridad fiscal que resulta de atribuir demasiada importancia a la inflación tiene otras consecuencias. Significa que los recursos no se están utilizando plenamente y que el derroche de recursos no sólo tiene un costo en materia de bienestar en la actualidad, sino también en el futuro. Las inversiones que se podrían haber hecho, tanto en capital físico como humano, no se hacen.

El FMI ha alegado que los países tienen que sentir el dolor; de esa manera el crecimiento será supuestamente más vigoroso en el futuro. Sin embargo, el dolor no es una virtud en sí mismo. En algunas de sus formas puede efectivamente impedir, no sólo el crecimiento presente, sino también el crecimiento futuro. Hay estudios macroeconómicos que apoyan ampliamente una hipótesis de raíz casi unitaria, de modo que las políticas que hoy conducen a una disminución del ingreso, también lo harán mañana, e igualmente en un futuro bastante lejano.

Quiero aclarar que no estoy defendiendo una inflación desenfrenada. ${ }^{49}$ Lo que estoy afirmando es que cuando un país tiene un gran volumen de recursos subutilizados, y al mismo tiempo existe deflación, no debemos preocuparnos obsesivamente por el hecho de que cierto grado de expansión fiscal podría causar un ligero aumento en los precios.

\section{Orientación al desarrollo, con sensibilidad ante las consecuencias sociales de las políticas económicas}

De manera similar, la reforma debe basarse en una concepción amplia del desarrollo, lo que en mi primera conferencia en honor de Prebisch denominé desarrollo como transformación. Porque el desarrollo es la transformación de la sociedad, no sólo es necesario tener en cuenta las consecuencias sociales de la reforma, sino que éstas deben ubicarse al frente y al centro.

\footnotetext{
${ }^{47}$ Eso es algo que también han destacado Fisher (1933) y Greenwald y Stiglitz (1993). Más recientemente se han expresado inquietudes acerca de la deflación también en Europa.

48 Véase, por ejemplo, Council of Economic Advisers (1996 y 1997); también Stiglitz (1997).

${ }^{49}$ Como han afirmado algunos críticos del FMI.
}

\section{Reconocimiento de las limitaciones de los mercados y una visión equilibrada del papel del Estado}

Es quizás evidente que la reforma debe basarse en una sólida comprensión de la economía. Pero del mismo modo que el Consenso de Washington fue criticado por centrarse en objetivos demasiado estrechos, también es posible criticarlo por haberse basado en un "modelo" equivocado o excesivamente simplista de la economía. No tuvo en cuenta las limitaciones derivadas de una información restringida y asimétrica, los mercados incompletos y la competencia imperfecta: todas ellas son limitaciones importantes en cualquier economía, pero especialmente en las economías en desarrollo. La opinión de que los mercados generan por sí solos eficiencia económica -0 , en términos más generales, que los mercados pueden por sí solos resolver los problemas básicos de la sociedad - se designa a veces con el nombre de fundamentalismo del mercado.

Se debió haber reconocido que, si bien los mercados pueden hallarse en el centro de una economía sana, el Estado tiene un papel importante que desempeñar. Uno de los problemas más graves de América Latina es la persistencia de un alto grado de desigualdad. Los mercados no solucionan este problema por sí solos, y las teorías económicas de la filtración o goteo preconizadas por los fundamentalistas del mercado sencillamente no funcionan; e incluso cuando funcionan lo hacen en forma demasiado lenta. Los mercados, por sí solos, no aseguran la estabilidad macroeconómica; y aunque la economía se recupere posteriormente de un shock adverso que dé lugar a altas tasas de desempleo, los mercados, dejados a su libre albedrío, funcionan con demasiada lentitud.

Es necesario entender el papel del Estado para llegar a una sólida comprensión de la economía. La visión que tenía el Consenso de Washington al respecto era con frecuencia desequilibrada. Consideraba que el Estado era parte del problema del desarrollo, y a menudo parecía abogar por un Estado minimalista. Los escándalos empresariales en que están envueltos hoy en día los Estados Unidos muestran el peligro que representan los mercados no regulados: han demostrado que los incentivos funcionan, pero no necesariamente en interés de la economía en su conjunto, ni tampoco del accionista común. Son fruto del mismo mantra de desregulación que se promovió en América Latina. Los Estados Unidos deberían haber aprendido la lección: la desregulación excesiva del sistema financiero durante la presidencia de Reagan (combinada con las 
tasas de interés excesivas a las que me referí anteriormente) desencadenó la debacle de las instituciones de ahorro y préstamos, no sólo costándole al contribuyente estadounidense miles de millones de dólares, sino más aún a la economía del país, debido a la asignación inadecuada de las inversiones.

El fundamentalismo del mercado se basa en la teoría de la mano invisible, en la eficiencia de los mercados sin restricciones. Pero hoy en día sabemos que, cuando la información es imperfecta y los mercados incompletos - problemas muy característicos de los países en desarrollo-, la mano invisible puede serlo simplemente porque no existe (véase, en particular, Greenwald y Stiglitz, 1986). Los fracasos del mercado abundan. Aunque haya varias empresas en un mercado, la escasez de información puede darle a cada una un cierto grado de poder monopólico. Esto suele suceder, por ejemplo, en los mercados de crédito, sobre todo en los que otorgan préstamos a pequeñas y medianas empresas, y en la comercialización de los productos agrícolas, especialmente en los países muy poco desarrollados. Este es, por ejemplo, uno de los motivos por los cuales, incluso en los Estados Unidos, no dependemos de empresas privadas para la comercialización de muchos productos agrícolas, desde las pasas de uva hasta las naranjas, sino que recurrimos a cooperativas. Es también uno de los motivos por los cuales las cooperativas de crédito han desempeñado tradicionalmente un papel tan importante. Como las instituciones económicas internacionales han exigido el abandono de las juntas de comercialización en varios países de África occidental, existe la preocupación, por lo menos en algunos casos, de que los agricultores se hayan beneficiado poco; el dinero que antes se utilizaba para ayudar a pagar los servicios públicos generales - y en algunos casos iba a parar a la corrupción - ahora se destina a apoyar los monopolios y mafias locales y a generar más corrupción local.

No existen teoremas generales que postulen que, en el mundo imperfecto en el que vivimos, la liberalización y la privatización contribuirán a mejorar el bienestar social general. Hay teoremas que han demostrado que la liberalización del comercio en presencia de mercados de riesgo imperfectos puede en realidad empeorar la situación de todos (Newbery y Stiglitz, 1984), y que muestran asimismo que las únicas condiciones en las cuales es posible asegurar que la privatización aumentará el bienestar son las mismas condiciones, sumamente restringidas, en las cuales era válido el teorema de Adam Smith de la mano invisible
(Sappington y Stiglitz, 1987). ${ }^{50}$ Las investigaciones empíricas respaldan este enfoque escéptico. ${ }^{51} \mathrm{Si}$ bien considero que tiene sentido que el Estado se retire de algunos sectores, como el del acero, en el que no tiene ninguna función obvia que cumplir, hay otros sectores, como el agua, la energía eléctrica, el transporte y el gas, en los que el Estado tendrá que desempeñar, de una manera u otra, un papel preponderante. Los problemas de regulación y desregulación que han salido a la luz en California y el Reino Unido, y en un sinfín de concesiones en América Latina, demuestran que la privatización no es ninguna panacea y puede de hecho empeorar las cosas. Y el proceso de privatización en sí, especialmente cuando se lleva a cabo con excesiva rapidez, es sumamente problemático.

Al fundamentalismo del mercado no le va mejor a nivel macro que a nivel microeconómico, y ello se debe en parte a que no reconoce los vínculos que existen entre ambos. Por supuesto que son pocos los fundamentalistas del mercado que creen hoy en día que los mercados se autorregulan tan bien por sí solos que no es necesario que el Estado intervenga en la política macroeconómica. Sin embargo, como ya se señaló, anteriormente se solía decir que el Estado, sobre todo en los países en desarrollo, era el origen de la inestabilidad macroeconómica: si ejercían prudencia fiscal y aplicaban una sólida política monetaria, los países no entraban en crisis. La crisis de Asia oriental acabó con ese mito. Los países de esa región habían registrado continuos superávit fiscales y muy poca inflación. La crisis se debió a la debilidad de las instituciones financieras, producto en parte de la falta de reglamentación.

No se trata simplemente de que las políticas del Consenso de Washington no hayan logrado su objetivo de estabilidad macroeconómica: en parte debido a las razones que cité anteriormente, en realidad contribuyeron a la inestabilidad macroeconómica, a través de las políticas de liberalización del mercado financiero y de capital.

\footnotetext{
${ }^{50}$ Véase también Simon (1991).

${ }^{51}$ Por ejemplo, Rodrik y Rodríguez (2001) en la esfera del comercio; en el caso de las corrientes de capital, Rodrik (1998) muestra que la liberalización de los mercados de capital, utilizando los métodos de medición del FMI, no conduce a la aceleración del crecimiento ni al aumento de la inversión. El hecho es que en la República de Corea las fábricas de acero, de propiedad del Estado, eran mucho más eficientes que la fábricas privadas de los Estados Unidos; que el sector energético de Francia, también estatal, es más eficiente que el de los Estados Unidos, que es privado; y que las empresas de los municipios y aldeas de China han estado entre las más emprendedoras del mundo.
} 
Resulta irónico que los países que han tenido más éxito - tanto los países industrializados adelantados de Europa y América del Norte, como las economías que crecieron en forma acelerada en Asia oriental- hayan captado intuitivamente la necesidad de establecer un equilibrio entre los mercados y el Estado. No existe correspondencia entre la versión de economía de mercado que se les está imponiendo a los países en desarrollo y, por ejemplo, la de los Estados Unidos. En ese país, el banco central (la Reserva Federal) no sólo se concentra en la inflación, sino también en el empleo y el crecimiento, y cuando hay una contracción económica se aceptan los déficit -incluso los grandes déficit. ${ }^{52}$ En los Estados Unidos hay una fuerte oposición a privatizar la seguridad social; además, el Estado es uno de los principales proveedores de energía eléctrica: incluso los más leves intentos de privatizarla chocan contra una fuerte resistencia. ${ }^{53}$

\section{No existe un único sistema "óptimo" ni una política "correcta"}

Una de las principales fallas de las políticas del Consenso de Washington fue la aparente creencia de que las reformas se podían dejar en manos de tecnócratas. Esto se basaba supuestamente en la premisa de que existía una única política económica óptima, y que era mejor confiar a los expertos la tarea de encontrar esa política. Pero no existe un único conjunto de políticas dominantes paretiano, es decir, uno que haga que todas las personas estén en mejor situación que si se hubiera aplicado cualquier otra política.

El problema estriba en que los mercados financieros, ${ }^{54} \mathrm{y}$ el FMI que suele representar sus intereses e ideo-

\footnotetext{
52 En 1992, el déficit de los Estados Unidos era de aproximadamente 5\% del PIB. Si los Estados Unidos hubieran privatizado la seguridad social (o si se excluyeran los ingresos de la seguridad social), el déficit aumentaría a $8 \%$ del PIB. Estas cifras son muy superiores a las de Argentina o de la mayoría de los demás países de América Latina que han sido criticados por su despilfarro presupuestario.

${ }_{53}$ Cabe preguntarse, habida cuenta del papel preponderante que desempeñan los Estados Unidos, cómo es posible que el FMI haya podido impulsar políticas tan diferentes a las de los Estados Unidos, especialmente durante una administración como la de Clinton, que parecía preocuparse tanto por la igualdad y por los pobres. La respuesta es que, en parte, los conceptos de justicia social no suelen ir más allá de las fronteras y, por otro lado, que la entidad que representa a los Estados Unidos en el Fondo es su Departamento del Tesoro, que a menudo trata de imponer puntos de vista marcadamente diferentes a los de otras entidades, incluso dentro del Poder Ejecutivo.

54 Simplifico demasiado cuando hago referencia a los "mercados financieros" ya que en ellos existen, por supuesto, muchos actores,
}

logía, actúan a menudo como si existiera un único conjunto de políticas dominantes que diese por resultado un óptimo de Pareto. Esto contradice lo que se enseña en una de las primeras lecciones de economía: la existencia de compensaciones (trade-offs) recíprocas. El papel del asesor económico es señalar esas compensaciones. La ciencia económica, por supuesto, hace hincapié en las limitaciones de nuestros conocimientos, en las incertidumbres vinculadas no sólo con el futuro sino también con las consecuencias de otras acciones posibles. El análisis de incidencia identifica no sólo quién gana y quién pierde a raíz de la aplicación de cada política, sino también quién corre con los riesgos inherentes a cada una de ellas. La función del proceso político es escoger entre las distintas opciones, con conciencia de las ventajas y desventajas que se compensan; de que algunos ganan como consecuencia de ciertas políticas mientras que otros pierden; de que algunas políticas entrañan mayores riesgos y otras menos; de que algunas implican que ciertos grupos deben asumir esos riesgos. Hay ventajas y desventajas que se compensan en el corto y el largo plazo. Cuando vienen asesores extranjeros a tratar de vender una política en particular, aduciendo que es la política correcta - dando por sentado que no hay compensaciones (trade-offs), ni riesgos, ni alternativas-, los gobiernos y los ciudadanos tienen derecho a sospechar.

Así también los defensores del capitalismo al estilo de los Estados Unidos han actuado como si hubiera una única forma dominante de organización económica, y así lo sintieron, especialmente después del colapso del comunismo. Aunque los acontecimientos recientes le han quitado parte de su brillo al capitalismo al estilo estadounidense, estos cruzados nunca han entendido realmente ni el sistema económico de los Estados Unidos y lo que ha hecho que funcione, ni el de los demás países; han subestimado el papel desempeñado por el Estado — por ejemplo, las políticas industriales, desde la agricultura hasta la alta tecnología, desde la creación de la industria de las telecomunicaciones en 1842, al instalarse el primer cable telegráfico, hasta la moderna internet, o las políticas regulatorias que son tan importantes para el funcionamiento de nuestros mercados de valores y sistemas bancarios-; incluso han subestimado el papel de las instituciones no

con diferentes intereses. Como ya he señalado, los inversionistas a largo plazo tienen intereses muy diferentes a los de los especuladores a corto plazo. Si bien los especuladores ganan con la variación y la inestabilidad, los inversionistas a largo plazo se benefician de la estabilidad. 
gubernamentales sin fines de lucro, ya sean cooperativas de crédito y agrícolas o universidades, hospitales y fundaciones.

De manera similar, han subestimado el éxito de otras versiones del capitalismo, como la de Suecia. Han descrito erróneamente las reformas de principios del decenio de 1990 en ese país como un abandono de su tradicional modelo de bienestar social. Y eso no es verdad: Suecia ha estado perfeccionando su sistema. El grado de protección social sueco sigue siendo muy superior al de los Estados Unidos, el papel del Estado en Suecia sigue siendo mucho más amplio que en los Estados Unidos, y sin embargo Suecia ha sido igualmente exitoso que los Estados Unidos en la Nueva Economía y ha mostrado una mayor estabilidad en el período actual de contracción económica. Yo me atrevería a sugerir que su éxito se debe, por lo menos parcialmente, a su sólido régimen de protección social: una parte esencial del éxito es la disposición a correr riesgos, y las fuertes redes de seguridad que ofrece Suecia aumentan la capacidad y el deseo de arriesgarse de las personas.

\section{Economía política}

Si es verdad, como hemos sostenido, que existen otras alternativas en materia de política económica, y si es cierto que éstas afectan de modo diferente a distintos grupos de personas, entonces es importante saber quiénes toman las decisiones y cómo se adoptan esas decisiones. Si hay una compensación (trade-off) entre el desempleo y la inflación, y si los trabajadores se preocupan más por el desempleo, mientras que a los mercados financieros les importa más la erosión del valor de sus activos nominales como consecuencia de la inflación, entonces los trabajadores y los mercados financieros verán las compensaciones desde puntos de vista diferentes; si se confían las decisiones relativas a la política monetaria a un banco central independiente controlado por intereses financieros, o se ordena al banco central que centre la atención únicamente en la inflación, es más probable que los resultados respondan a los intereses financieros y no a los intereses de los trabajadores.

Una de las principales reformas de América Latina ha sido su democratización. Se reconoce cada vez más que la democracia electoral — cuando las elecciones se compran, ciertos intereses particulares controlan los medios de difusión, o incluso cuando los ciudadanos carecen de los conocimientos necesarios para ser votantes informados- puede no ser suficiente por sí sola. ¿Qué pensarán de la democracia electoral los dos tercios de la población de Venezuela, que siguen viviendo en la pobreza en un país rico en petróleo, donde los frutos de su riqueza han ido a parar a manos de determinados grupos? ¿Qué pensarán de esa democracia electoral que, por lo menos antes de que Chávez asumiera la presidencia, no hacía más que perpetuar esa situación? Hoy en día, en toda la región, los que han sido privados de sus derechos civiles en el pasado están exigiendo que se les oiga. La democracia electoral de antaño, cualesquiera fueran sus méritos, no ha atenuado sus penurias. Eso es lo que saben con certeza.

Existe sin duda una estrecha conexión entre el régimen político y el éxito económico. ${ }^{55}$ Los países asolados por disturbios sociales y políticos no ofrecen un clima propicio para los negocios. Las políticas del pasado han engendrado un círculo vicioso: políticas macroeconómicas fallidas han llevado a un alto nivel de desempleo que a su vez ha conducido, o por lo menos contribuido, a la violencia urbana y la guerra de guerrillas; éstas, también a su vez, han desalentado la inversión e impedido el crecimiento. La estabilización - o, más exactamente, la estabilización mal enfocada, con excesiva preocupación por eliminar la inflación mediante políticas fiscales y monetarias que producen una contracción excesiva de la actividad económicano sólo no conduce por sí sola al crecimiento, sino que alimenta esa espiral descendente. La sensación de privación de derechos, de políticas económicas dictadas por intereses particulares, ya sea en sus países o, aun peor, en los países industrializados avanzados, sólo sirven para acentuar la insatisfacción.

Existen otros vínculos entre el éxito económico y la política. La concentración de la riqueza, incluso en regímenes democráticos, puede dar origen a la concentración de poder político, lo que limita las posibilidades de reglamentación o de tributación redistributiva, o de aumentar los impuestos, menoscabando la capacidad del Estado de cumplir sus funciones vitales. Al mismo

\footnotetext{
${ }^{55}$ Esta lista no pretende ser exhaustiva. La bibliografía más reciente sobre el desarrollo ha subrayado la importancia de la propiedad y la participación para el éxito del desarrollo. Véase, por ejemplo, Stiglitz (2001b). Para que haya una participación significativa en el proceso electoral es preciso, por supuesto, que los ciudadanos estén informados acerca de las actividades y los planes de su gobierno. Esto implica que la transparencia del gobierno y el derecho a saber de los ciudadanos, consagrado en leyes sobre la libertad efectiva de información, son esenciales. Mientras Suecia ha tenido ese tipo de legislación durante más de dos siglos, en los últimos años son más y más los países que han introducido reformas de esa naturaleza.
} 
tiempo, la inestabilidad extrema ha causado una erosión de la clase media, es decir, de los grupos que más apoyo han prestado al establecimiento del imperio de la ley, tan necesario para el eficaz funcionamiento de una economía de mercado.

Las políticas del Consenso de Washington prestaron escasa atención a las cuestiones relativas a la distribución. No obstante, la política y la economía están íntimamente relacionadas. Aun si nos preocupara poco la pobreza o la desigualdad, la distribución del ingreso, tanto directa como indirectamente, a través de los procesos políticos, es importante para el desempeño de la economía. ${ }^{56}$ Estos aspectos deben ser elementos esenciales de cualquier agenda para la reforma de las reformas.

\section{Más allá de los principios económicos}

He dedicado la mayor parte de esta sección a analizar aspectos relacionados con los principios económicos, pero debo mencionar brevemente cuatro cuestiones filosóficas más amplias. En primer lugar, ha habido un cambio importante en las nociones de igualdad, al ponerse más énfasis en la igualdad de oportunidades, que en la igualdad de resultados. En segundo lugar, se ha reconocido la importancia de la comunidad, de la necesidad de acción colectiva, de la necesidad de ir más allá del individualismo para generar un sentido de solidaridad social. Sin embargo, la acción colectiva, la comunidad, puede expresarse no sólo a través del gobierno, en sus diversos niveles, sino también por conducto de la sociedad civil y las organizaciones no gubernamentales, que pueden ser medios importantes, no sólo de acción, sino también de expresión de las opiniones. En tercer lugar, en las últimas décadas se ha ampliado el concepto de los derechos humanos fundamentales, que ya no abarcan solamente los derechos y las libertades civiles, la libertad de expresión y de prensa, el derecho de reunión y la libertad religiosa, sino también los derechos económicos, el acceso a la atención primaria de la salud y el derecho a ganarse la vida. Puede haber conflictos entre esos derechos, y entre los derechos de unas personas y los de otras, y tiene que haber maneras de resolver esos conflictos. Ésta es una de las esferas de acción de la responsabilidad colectiva. Y por último, con los derechos vienen las responsabilidades, tanto a nivel individual como de la comunidad. Cuáles son esas responsabilidades, y cuáles deben ser las consecuencias de su inobservancia, son algunas de las cuestiones de política pública más difíciles de resolver, y van mucho más allá del alcance limitado de este artículo.

\section{VI}

\section{Elementos de una agenda de reforma}

Los principios reseñados en la sección anterior sirven de guía para reflexionar sobre la manera de reformar la reforma. He criticado al Consenso de Washington no sólo por lo que figuraba en su agenda, sino también por lo que no figuraba en ella; y al examinar lo que contenía y lo que le faltaba, podremos tener una mejor visión tanto del papel de la ideología como del papel de los intereses. En algunos países, la aparcería es el método más usual de explotación agrícola. En el régimen de aparcería, el 50\% del producto (y en algunos casos más) se entrega al dueño de la tierra. La atenuación de los incentivos es obvia. El FMI suele expresarse enér-

\footnotetext{
56 Se reconoce ampliamente, por ejemplo, que parte del éxito de Asia oriental se debió a su activa promoción de políticas igualitarias. Véase Stiglitz (1996) y las referencias citadas en esa obra.
}

gicamente en contra de los impuestos altos porque reducen los incentivos. Sin embargo, los efectos adversos de la aparcería en las personas muy pobres no son menos importantes. Aun así, la reforma agraria nunca se ha incluido en la agenda del FMI, o por lo menos nunca ha figurado en un lugar prominente, por razones obvias.

Para destacar la diferencia fundamental que existe entre la forma en que el Consenso de Washington encara el desarrollo y el criterio que yo propongo aquí, me referiré en primer lugar a las partes de la agenda que abordan aspectos que anteriormente habían sido desechados de plano. Cada uno de los elementos enumerados a continuación podría ser objeto de un trabajo separado, y hay muchas reformas más — por ejemplo, de las instituciones políticas - que no alcanzo a analizar aquí. He criticado el Consenso de Washington por 
adoptar un enfoque excesivamente estrecho; también se podría objetar que la agenda de reformas que figura a continuación es demasiado amplia y no centra la atención en aspectos específicos. Sin embargo, considero que el Banco Mundial ha destacado con acierto la necesidad de aplicar un enfoque integral, ${ }^{57}$ y si bien ningún gobierno puede prestar idéntica atención a todos los elementos al mismo tiempo, sería un error pasar por alto cualquiera de estas dimensiones.

\section{Movilización social}

El elemento más importante de la movilización social es, posiblemente, la educación. Si bien el aumento del gasto en educación se ha convertido en parte del mantra tanto de la izquierda como de la derecha, no se ha prestado tanta atención a los aspectos relativos a la asignación del gasto y al contenido de la educación. Las desventajas educativas de los pobres comienzan antes de que ingresen a la escuela, y es por ello que el Proyecto Headstart ha desempeñado un papel tan importante en la política educativa de los Estados Unidos.

La educación reviste tanta importancia porque influye en la mentalidad de los individuos de la próxima generación; incide, por ejemplo, en su actitud frente al cambio y la tradición. Les ayuda a conocer mejor sus derechos y sus responsabilidades, el papel que deben desempeñar los individuos y el Estado. En el siglo XIX, una de las funciones que desempeñó la educación pública en su etapa inicial de desarrollo fue la de formar una fuerza de trabajo disciplinada, con la educación mínima necesaria para que lo fuera. Hoy en día queremos formar ciudadanos que sepan hacer valer sus derechos y que estén preparados para seguir un proceso de aprendizaje a lo largo de toda su vida, que tengan los conocimientos necesarios para desenvolverse en una sociedad moderna (por ejemplo, conocimientos de informática) y que dominen los idiomas indispensables. Durante el próximo cuarto de siglo, por lo menos, en muchos de los países más pobres una gran parte de sus habitantes permanecerá en el medio rural. Para ellos, la educación no tiene que ser necesariamente sólo una forma de salir de allí, sino que una forma de ascender: no capacitarse únicamente para empleos urbanos, sino adquirir los conocimientos y habilidades necesarios para aumentar la productividad dentro del sector rural. Lo que aprendan con respecto a la salud y el medio ambiente puede influir enormemente en la calidad de su

57 Véase, por ejemplo, Wolfensohn (1998) y Stiglitz (1998). vida cotidiana y en la sostenibilidad del medio ambiente, e incluso en su nivel de vida a largo plazo.

El espíritu empresarial será la clave del futuro, y esa cualidad, además de los otros conocimientos y habilidades necesarios para alcanzar el éxito en los negocios, también puede enseñarse.

En algunos países en desarrollo se ha comprobado que los planes de microcrédito son un importante instrumento de movilización social. En el análisis del microcrédito se ha hecho bastante hincapié en los aspectos económicos, en la concesión de préstamos a hogares pobres, especialmente a mujeres pobres, que de lo contrario no tendrían acceso a crédito. Sin embargo, los impulsores originales del microcrédito pensaban que había también otros intereses en juego. Querían desarticular las estructuras de poder en las aldeas locales, dando más poder económico a las mujeres pobres, que hasta ese momento se habían visto privadas de sus derechos. Es por eso que uno de los principales proveedores de microcrédito, el Comité de Fomento Rural de Bangladesh (BRAC), ha complementado los programas de microcrédito con programas de educación, inclusive los que apuntan principalmente a la educación de la mujer, haciendo hincapié en el medio ambiente, la salud y los derechos jurídicos.

Los medios de difusión pueden desempeñar un papel importante - a menos que estén bajo el control de unas pocas personas acaudaladas y se encuentren muy concentrados, como sucede en muchos países. Si bien el gobierno tiene que aprobar, y hacer cumplir, leyes que garanticen la diversificación de los medios de difusión, también debe asegurarse de que por esos medios se escuchen más voces, y para ello puede, por ejemplo, dar apoyo a las estaciones de radio comunitarias y a radios controladas por organizaciones no gubernamentales.

En los últimos años se ha prestado una atención cada vez mayor al medio ambiente. No obstante, en algunos sectores al parecer se considera que un medio ambiente limpio es un lujo de ricos, y que los pobres carecen de los recursos necesarios para ocuparse de esas cosas. Sin embargo, yo me atrevería a sostener ${ }^{58}$ que, por lo menos en muchos casos, el crecimiento, la reducción de la pobreza y la protección del medio ambiente se complementan entre sí: la erosión de los ejidos o la falta de control del crecimiento demográfico significarán que, en el futuro, no sólo empeorará el medio ambiente sino que además habrá más pobreza.

\footnotetext{
58 Véase también Dasgupta (1995).
} 
En muchas partes del mundo las comunidades han encontrado tradicionalmente formas de ordenar el medio ambiente en aras del bien común. La "tragedia de los comunes" ${ }^{59}$ que a veces se describe como la falta de una definición clara de los derechos de propiedad sobre los recursos comunes, es muchas veces el resultado de la irrupción de fuerzas (imperfectas) del mercado en las culturas tradicionales. En términos más generales, en trabajos realizados recientemente en el Banco Mundial ${ }^{60}$ se ha destacado la importancia de la cultura, que refuerza el sentido de identidad y comunidad, tan importantes para el bienestar de largo plazo.

En casi todo el mundo el proceso de desarrollo ha ido acompañado de la urbanización. Hoy en día, uno de los principales desafíos que deben afrontar muchos países en desarrollo es cómo mejorar la calidad de vida en las ciudades. Un aspecto de ese problema es cuidar el medio ambiente, creando sistemas urbanos de transporte público que eviten la contaminación del aire que sofoca a tantas ciudades e implantando parques públicos que no sólo ofrezcan un lugar de descanso a las personas, sino que también ayuden a crear un sentido de comunidad.

Otro aspecto del desarrollo vinculado a la urbanización es el debilitamiento de las redes tradicionales de protección social que proporcionaban anteriormente las comunidades y las familias. Como ya lo mencioné, la inseguridad es una importante dimensión de la pobreza, y si bien he argumentado que las reformas económicas deben diseñarse con el propósito de aumentar la estabilidad económica y reducir el riesgo, en los hechos, por más exitosas que sean esas reformas, los países en desarrollo sufrirán shocks. El gobierno debe ayudar a crear una red de protección social trabajando con organizaciones no gubernamentales que pueden a menudo ofrecer mecanismos de ejecución eficaces. En algunos países se ha manifestado preocupación por los excesos cometidos en ciertas partes de la red de seguridad social y, en particular, en los programas de pensiones. Es indudable que habrá que reformarlos. En muchos casos, los programas estaban mal diseñados y empezaron a aplicarse incentivos perversos, como el de otorgar importantes aumentos de sueldo poco antes de la jubilación. Esos incentivos perversos tuvieron a su vez efectos indebidos, que se manifestaron en pensiones muy superiores a las previstas inicialmente. No obstante, a medida que avancen las reformas, deberán

59 "La tragedia de los comunes" (Hardin, 1995), publicado originalmente en inglés en 1968.

${ }^{60}$ Rao y Walton (2003). ser sensibles a las inquietudes subyacentes que dieron origen a estos programas.

\section{Mayor equidad y lucha contra la pobreza}

En el Consenso de Washington se le dio poca importancia a la pobreza, quizás porque se creía que con el tiempo los beneficios del crecimiento se filtrarían hacia abajo. Sin embargo, existen pocos motivos para pensar que eso pudiera suceder. Y, por las razones ya mencionadas en secciones anteriores de este trabajo, lo más probable es que las políticas del Consenso de Washington hayan agravado el problema de la pobreza.

Como punto de partida de una agenda contra la pobreza, los gobiernos deberían asumir el compromiso de crear empleos - trabajo decoroso, como ha dicho la Organización Internacional del Trabajo (огт) para todos: tener un empleo debería ser un derecho fundamental de todo miembro de la sociedad que desee trabajar, y el gobierno tiene el deber fundamental de garantizar el cumplimiento de ese derecho. Todo gobierno que fracasa en esta tarea, que fracasa de manera lamentable, como suele suceder, debería perder su mandato.

Es pues necesario sustituir ese enfoque restringido que se preocupa únicamente de combatir la inflación, por un criterio más amplio que apunte a fomentar el crecimiento y generar empleos. Estamos conscientes de que existen algunos obstáculos que impiden la creación de puestos de trabajo, entre ellos la falta de crédito y los tipos de cambio sobrevaluados. ${ }^{61}$ De ahí la gran importancia que reviste la gestión macroeconómica: si da lugar a tipos de cambio sobrevaluados y a altas tasas de interés, no habrá generación de empleo. Pero también debemos entender que los mercados de capital no son como los mercados normales, en los que la eficiencia exige un "precio único" y que podrían describirse acertadamente como si fueran una subasta. En todos los países, el gobierno ha desempeñado un papel importante en la concesión de créditos a estudiantes, préstamos para vivienda, créditos a agricultores y pequeñas y medianas empresas y créditos a las exportaciones. Es verdad que algunas veces se ha abusado de estos programas, pero ahora conocemos mejor la forma de protegernos de esos abusos.

\footnotetext{
${ }^{61}$ Existen otros, como las medidas excesivas de protección del empleo, que aumentan los costos de contratación de un trabajador. Sin embargo, por las razones que ya mencioné, no creo que esto haya sido un obstáculo crucial, por lo menos en muchos de los países de la región.
} 
El fomento de la equidad y la lucha contra la pobreza deben empezar con programas educativos y de salud para los niños, pero deben continuar a lo largo de toda la vida. Hoy en día conocemos los efectos debilitantes que pueden tener las enfermedades y disponemos de los medios para reducirlas y mitigar sus consecuencias. Pero la salud es algo más que la simple atención médica; debemos propiciar estilos de vida saludables, por ejemplo combatiendo el tabaquismo y el uso indebido de estupefacientes, y promoviendo el consumo de vegetales y una dieta balanceada.

El éxito en la pugna por la equidad y contra la pobreza requiere una potenciación tanto económica como política. En el sector rural, eso conlleva una reforma agraria significativa que acompañe la redistribución de la tierra con otorgamiento de créditos y acceso a la tecnología. El registro de la propiedad de la tierra es importante, pero sólo debe verse como un componente de un programa más amplio. Dicho registro facilita el uso de la tierra como garantía, pero sólo resultará eficaz cuando existan mercados de tierras que funcionen bien.

Tiene que haber programas que promuevan el ahorro tanto en el sector rural como en el urbano. Es probable que los colapsos de sistemas bancarios ocurridos recientemente hayan socavado la confianza en el sector financiero. Es preciso buscar la forma de otorgar garantías estatales fiables a los pequeños ahorristas, y en los países en crisis este tema de la confianza debería tenerse en cuenta en las estrategias de reestructuración de los bancos. Una forma posible de promover la utilización de las instituciones financieras nacionales es que el gobierno aporte fondos de contrapartida respecto de las cuentas de ahorro pequeñas (una suerte de "crédito impositivo sobre el ingreso devengado", que pueda hacerse efectivo, para los ahorros de personas de bajos ingresos).

La tributación tiene que ser más equitativa. El IVA no es un impuesto equitativo, y en la mayoría de los países en desarrollo es un impuesto que ni es compatible con la eficiencia económica ni promueve el crecimiento, porque es un tributo que grava al sector formal, que es el sector que debería promoverse en el proceso de desarrollo. Y como los muy acaudalados suelen gastar montos importantes en el exterior, ni siquiera representa un impuesto proporcional sobre el consumo.

El objetivo de la política tributaria debería ser la promoción de la equidad, la estabilidad y el crecimiento sostenible, y deberíamos estar buscando estructuras impositivas resistentes a la corrupción. Por ende, de- beríamos depender mucho más de los impuestos indirectos, como los que gravan los automóviles de mayor tamaño y los bienes de consumo lujosos, que son consumidos en su mayor parte por los ricos (y en su mayor parte importados). Tendríamos que gravar los productos básicos como el petróleo y el carbón que dañan el medio ambiente; imponer tributos más altos sobre las rentas, tales como las vinculadas a los recursos naturales o los monopolios o cuasimonopolios, por ejemplo en los sectores de las telecomunicaciones o del cemento en algunos países latinoamericanos. Deberíamos gravar con fuertes impuestos progresivos las grandes residencias, las grandes extensiones de tierra, y pensar en la forma de inducir a los terratenientes a contratar más mano de obra, por ejemplo dándoles un descuento o crédito fiscal para la contratación de trabajadores. Deberíamos incluso considerar la posibilidad de gravar con impuestos las corrientes de capital de corto plazo cuando entran y salen de un país, ajustando la tasa del impuesto a las circunstancias económicas (en cuyo caso tendríamos que emplear otras medidas para estabilizar las corrientes de capital y reducir la exposición al riesgo, como las disposiciones relativas a la posibilidad de descontar impuestos de la deuda de corto plazo en moneda extranjera, y normas bancarias dirigidas a desalentar la adquisición de deudas a corto plazo en moneda extranjera, las que aparentemente generan externalidades muy importantes, como ya hemos señalado).

\section{La creación de un clima propicio para los ne- gocios}

Llegamos por último a una parte de la agenda que ha pasado a ser moneda corriente: la creación de un clima propicio para los negocios, que no sólo atraiga a los inversionistas extranjeros, sino que ofrezca un entorno agradable a los inversionistas nacionales.

Nuestra visión de la forma en que el gobierno puede lograr este objetivo representa uno de los cambios más importantes en la concepción del desarrollo en los últimos años. En los decenios que siguieron inmediatamente a la segunda guerra mundial, la atención se centró en la construcción de infraestructura. En las décadas de predominio de las ideas del Consenso de Washington, se ponía el énfasis en quitar de en medio al gobierno mediante, por ejemplo, la minimización de los reglamentos y la privatización de la infraestructura. Actualmente sabemos que el gobierno cumple una función importante, y que esa función va más allá de los proyectos, e incluso de las políticas (como las que pro- 
mueven la estabilidad macroeconómica), aunque unos y otras siguen siendo factores de peso: el mercado con frecuencia no emprende la ejecución de proyectos de infraestructura necesarios, como la construcción de caminos rurales, y, como ya hemos señalado, la privatización de la infraestructura ha tropezado con muchos problemas, y el mercado por sí solo no ha generado estabilidad macroeconómica. Los mantras del desarrollo de hoy en día hacen hincapié en la importancia de las instituciones, aunque incluso en este tema el análisis muchas veces no es equilibrado, ya que atiende más a los problemas que plantea la corrupción en el sector público que a las deficiencias en la conducción de las empresas en el sector privado; en la creación de un banco central independiente abocado a combatir la inflación, más que de uno que represente los intereses de los ciudadanos, con un enfoque equilibrado de la lucha contra la inflación y la promoción del crecimiento y el empleo, o de uno que se ocupe de la creación de instituciones financieras que garanticen la circulación del crédito en toda la sociedad. Lamentablemente, podemos decir más acerca de lo que se necesita, de lo que podemos decir sobre cómo crear lo que es preciso crear.

Ya me he referido a grandes rasgos a dos de los elementos fundamentales: la educación y el crédito. Los países europeos que han tenido un buen desempeño en los últimos tiempos, como Irlanda y Portugal, tienen sistemas bancarios locales, fuertes y debidamente reglamentados, y buenos sistemas educativos. En los Estados Unidos, durante los siglos XIX y XX, se hizo gran hincapié en los bancos locales, porque se reconocía la importancia de la información local para la concesión de préstamos; existía también la preocupación legítima de que un sistema bancario concentrado, cuyo centro sería Nueva York, absorbería recursos del resto del país e impediría un desarrollo más amplio. Fue sólo en el decenio de 1990 que se autorizó la actividad bancaria a escala nacional. En cambio, a nivel internacional, insistimos en que los países pequeños se abrieran a los bancos internacionales, sin preocuparnos demasiado por saber si esos bancos otorgarían créditos a las pequeñas y medianas empresas. El caso de Argentina demostró que la existencia de bancos internacionales en un país no garantiza la estabilidad de su sistema bancario. Algunos pensaron que las casas matrices de los bancos acudirían en auxilio de sus filiales; por cierto, hay muchos depositantes a los que aparentemente se les indujo a creer que así sería. Sin embargo, eso no ocurrió. Para garantizar un tratamiento igualitario y promover el crecimiento, es necesario aprobar algu- na reglamentación análoga a la ley de reinversión en las comunidades, a fin de obligar a los bancos que obtienen recursos en un país a que presten nuevamente el dinero dentro de ese país y, en una proporción importante, a las pequeñas y medianas empresas nacionales.

Habría que probar otras medidas para promover las pequeñas empresas, como las incubadoras, que han permitido obtener éxitos notables en distintas partes del mundo.

El sello distintivo del éxito del período anterior en América Latina fueron las políticas industriales. En el último cuarto del siglo XX estas políticas adquirieron injustificadamente una mala reputación. Ya describí el importante papel que ellas desempeñaron en el desarrollo de los Estados Unidos, y también considero que fueron importantes para el éxito de Asia oriental. No obstante, una política que dio buenos resultados en una época puede ser menos eficaz en otra, y el sistema de comercio mundial ha puesto limitaciones en cuanto al uso que pueden hacer los gobiernos de algunas técnicas utilizadas comúnmente, aunque desearan hacerlo en mayor medida. No quiero repetir los problemas que se plantearon con las estrategias de sustitución de las importaciones en América Latina, ni los abusos de la política industrial. Al igual que muchas de esas políticas, la política industrial puede ser un instrumento eficaz para impulsar el crecimiento, pero también puede emplearse de manera indebida. Actualmente conocemos algunas formas de aumentar la probabilidad de que dichas políticas sean eficaces y reducir la probabilidad de abuso. La Administración Clinton, para la cual trabajé, tenía la firme convicción de que estas políticas podían cumplir una función importante en el desarrollo de la economía de los Estados Unidos, y de que existían motivos aún más imperiosos para promover su aplicación en los países en desarrollo. El hecho de que el Departamento del Tesoro de los Estados Unidos se sintiera más inclinado a sacar de grandes apuros a Wall Street o a otros elementos del bienestar empresarial — que a ayudar a ciertas formas de intervención en el mercado que fomentaban la tecnología, tanto dentro como fuera del país- refleja más la influencia que ejercían los intereses creados y la impureza de la ideología que la sensatez de determinadas políticas económicas. El gobierno ha desempeñado una función catalizadora en el pasado, y puede hacerlo en el futuro: puede no sólo contribuir a que los mercados funcionen mejor, sino que puede también ayudar a dar forma a la economía y, lo que es más importante, puede hacerlo a través de la infraestructura 
física, institucional y educativa, garantizando, por ejemplo, que exista una fuerza de trabajo capacitada. En la economía de hoy en día, parte de esa función catalizadora consiste en ayudar a promover el reconocimiento de los cambios estructurales que se han observado en todo el mundo: la reducción del sector manufacturero, el crecimiento del sector de los servicios, la capacidad de los servicios de cruzar fronteras al igual que los bienes. Los países que han crecido con mayor rapidez en la última década - - y que han creado más empleos - han sido aquellos que se han adaptado a esos cambios y que incluso los han apoyado.

Es indudable que la reglamentación puede sofocar a las empresas; por lo tanto es necesario reexaminarla periódicamente, reconociendo que el objetivo no debe ser la desregulación, sino la definición del marco regulatorio adecuado, que permita el funcionamiento de la economía de mercado y minimice cualquier carga normativa innecesaria, proporcionando, por ejemplo, centros integrales de ayuda (ventanillas únicas). Se ha demostrado que la incertidumbre regulatoria $-\mathrm{y}$ la corrupción, que suele asociarse a la discrecionalidad reglamentaria - es un importante impedimento para la actividad comercial. Hay formas de vigilar la corrupción y actualmente contamos con estrategias para reducirla. Hoy en día sabemos que la corrupción puede, por supuesto, producirse tanto en el sector privado como en el sector público, y que la transparencia puede ser un antídoto por lo menos parcialmente eficaz contra la corrupción. Es necesario establecer marcos jurídicos que garanticen la correcta conducción de las empresas - un sistema de frenos y contrapesos que proteja a los accionistas de la codicia desenfrenada de los directivos, a los accionistas minoritarios de los accionistas mayoritarios, a los tenedores de bonos de los accionistas, a los tenedores de bonos de menor jerarquía de los de mayor jerarquía-, pero es difícil elaborar ese marco jurídico, y aplicarlo lo es aún más.

La estabilidad macroeconómica es crucial para el mantenimiento de un clima favorable para la actividad empresarial. Me refiero a la verdadera estabilidad, no a lo que se designó con ese nombre durante el último decenio. Las recesiones y las depresiones son perniciosas para los negocios, y las políticas - como la liberalización de los mercados de capitales y los reglamentos bancarios mal diseñados y los que incorporan desestabilizadores automáticos-que conducen a la inestabilidad deben evitarse. En efecto, los gobiernos deben impedir la inflación excesiva, del mismo modo que deben evitar la deflación. Pero la estabilidad va más allá de eso.
El mantenimiento de la estabilidad en un entorno sumamente inestable, con enormes fluctuaciones de los tipos de cambio y de los precios de los productos básicos, no es una tarea fácil. Los países tendrán que aprender a manejar esos riesgos, inclusive mediante la diversificación de los productos básicos, la creación de fondos de estabilización, la utilización de políticas tributarias y crediticias (y no sólo monetarias) anticíclicas y la modulación de las corrientes de capital de corto plazo.

Existen, obviamente, muchos temas más a los que no me he referido: es posible que sea necesario mejorar los sistemas de transporte, especialmente en las zonas rurales, para que la población del medio rural pueda tener acceso a los mercados. En algunos casos hay "mercados ausentes", o la competencia es tan limitada que los pequeños productores y consumidores terminan siendo explotados o se les impide la entrada. Es importante que exista una competencia efectiva y políticas regulatorias; también en este caso, las fallas pueden deberse a que el gobierno cumple una función demasiado reducida o a que interviene en exceso. En algunos casos, el gobierno debería considerar la posibilidad de promover las cooperativas, que han desempeñado un papel tan importante en muchas economías de mercado, inclusive en los Estados Unidos y los países escandinavos.

Si bien he destacado la importante función que incumbe al gobierno, éste sólo podrá desempeñarla si no queda atrapado en las redes de intereses particulares y si está relativamente exento de corrupción. Es necesario el imperio de la ley y que ésta se haga cumplir eficazmente y con justicia. En el sector público puede haber la misma preocupación por la eficiencia y la eficacia que existe en las economías de mercado que funcionan bien. Éstos son desafíos para todos los países, no sólo para los países en desarrollo. Son batallas que nunca terminan: siempre habrá intereses particulares que querrán utilizar el poder del Estado para promover sus intereses, en lugar de fomentar el crecimiento equitativo y sostenible. La buena nueva es que hemos visto países, tanto en el mundo en desarrollo como en el desarrollado, que han hecho grandes progresos en la formación de gobiernos eficaces y transparentes, que dan respuesta a los problemas y cumplen con su responsabilidad democrática de rendir cuentas.

En esta sección me referí en menor medida a las cuestiones más convencionales, como la reforma necesaria de la privatización y la liberalización. Actualmente los fracasos del pasado ya están suficientemente documentados. Tampoco dije mucho acerca de la 
reforma del mercado laboral, salvo cuando mencioné el mantra simplista que propugna la flexibilización de ese mercado, y advertí que esa medida podía no conducir a un aumento del empleo, pero sí a un incremento

\section{VII}

\section{Conclusiones}

He esbozado aquí una nueva agenda de reforma. Vacilé en utilizar este término por las connotaciones negativas que ha adquirido la palabra reforma en los últimos años. Sin embargo, reforma significa simplemente cambio, y ha sido necesario reformar la propia reforma. En esta última parte me voy a referir a lo que pueden hacer los países de la región habida cuenta del régimen internacional actual. Como ya lo he dicho, ese régimen adolece de problemas fundamentales: la falta de equidad del sistema de comercio mundial se encuentra hoy en día ampliamente documentada, y el sistema financiero mundial no sólo no es equitativo, sino que es intrínsecamente inestable. Dado que la suma de los déficit mundiales tiene que ser igual a la suma de todos los superávit, si algunos países, como Japón y China, siguen teniendo superávit, los demás países — considerados en conjunto- deben reflejar un déficit. Y si los países deficitarios tienden a caer en crisis, entonces éstas son de hecho inevitables. Si un país, para hacer frente a sus problemas, modifica el tipo de cambio, a medida que su déficit se transforma en superávit (como le sucedió a la República de Corea después de la crisis), algún otro país tendrá que entrar en déficit, o aumentar su déficit actual. Esta es la aritmética simple de las finanzas mundiales. ${ }^{63}$

Los países de la región han aprendido - a costa de grandes sufrimientos- lo que significan la inestabilidad de los mercados mundiales de capital y sus ineficiencias; pese a que los principios económicos generalmente aceptados indican que los países ricos del mundo son los que están en mejores condiciones de asumir los riesgos derivados de las fluctuaciones de las tasas de interés y los tipos de cambio, y que, por ende, en un mercado que funciona bien, tendrían que sopor-

\footnotetext{
62 Véase, por ejemplo, Stiglitz (2002b) o Stiglitz (1999a).

63 Actualmente estoy trabajando con mi colega Bruce Greenwald en la preparación de un libro en el que detallamos estas imperfecciones y proponemos una serie de reformas. Véase también Soros (2002).
}

de la pobreza y la inestabilidad. Me he expresado sobre muchos de estos temas en otros trabajos, ${ }^{62}$ pero una exposición más completa de la agenda de reforma quedará para otra ocasión. tar esos riesgos, en la práctica son los países pobres los que se ven obligados a hacerlo.

Los países de la región deberían aprovechar las ventajas de la globalización, pero tratando de adaptarla a sus propias exigencias. Un Área de Libre Comercio de las Américas podría beneficiar enormemente a estos países, pero sólo si los Estados Unidos abren realmente sus mercados, todos sus mercados, a los productos de la región, lo que implica no solamente abrir sus mercados agrícolas y textiles, sino también eliminar los subsidios agrícolas y suprimir las innumerables barreras no arancelarias que los Estados Unidos han empleado incluso en contra de sus vecinos, Canadá y México. Un acuerdo de libre comercio no puede utilizarse para promover políticas bajo el rótulo de "medidas de protección de la inversión", que de lo contrario serían inaceptables (como en el caso tal vez del Tratado de Libre Comercio de América del Norte), o de un régimen de propiedad intelectual no equilibrado (como podría decirse que fue el que emanó de la Ronda Uruguay). La liberalización de los mercados de capital ha sido una de las principales causas de la inestabilidad de la región, e incluso el FMI ha llegado a reconocer que crea un riesgo sin generar la consiguiente recompensa. No obstante, en sus acuerdos comerciales bilaterales (con Singapur y Chile), los Estados Unidos han insistido en esa liberalización.

En este artículo no sólo he tratado de señalar las deficiencias de la agenda de reforma anterior, sino también de vincular esas deficiencias con las políticas: el fracaso de la reforma no fue simplemente un producto de la mala suerte o, como les gustaría decir a los defensores del Consenso de Washington, de una implementación inadecuada. Lo menos que cabe esperar de las políticas es que estén bien formuladas, para que podamos aplicarlas los simples mortales en el volátil ambiente en que vivimos. Sin embargo, los fracasos fueron aún más fundamentales: tuvieron que ver con lo que se incluyó y con lo que no se incluyó en la 
agenda, con lo que se subrayó y con lo que no se destacó. Muchas de las "reformas" en las que se centró la atención contribuyeron a exacerbar los problemas de la región. He dedicado un tiempo considerable a hablar de algunos aspectos que han recibido menor atención de la que merecían.

He argumentado que es preciso formular un conjunto de políticas económicas que reflejen un mayor equilibrio entre los mercados y el Estado; que reconozcan el papel fundamental que ambos deben desempeñar para que la economía funcione y acepten que ese papel pueda cambiar con el tiempo, de acuerdo con la solidez de las instituciones tanto del sector público como del privado; y que reconozcan asimismo que las estrategias de desarrollo deben apuntar al fortalecimiento simultáneo de ambos sectores. ${ }^{64}$ También es necesario que dejemos de concentrarnos excesivamente en la inflación, para prestar más atención a la creación de empleos; y que no pensemos tanto en la reestructuración y la privatización de las empresas existentes, sino más bien en la creación de empresas nuevas. Debemos apartarnos de la teoría económica de la filtración o goteo (incluidas sus versiones más modernas, a las que me he referido con el nombre de "trickle down plus"), que añaden a la concepción simplista del Consenso de Washington una preocupación por la educación primaria, especialmente para las niñas, y centrar nuestra atención en la pobreza —en todas sus dimensiones-, en el convencimiento de que no podemos separar las políticas económicas de su contexto social y político. Como enfaticé en la conferencia que dicté en la UNCTAD en honor de Prebisch, el desarrollo no consiste únicamente en acumular capital y asignar los recursos de manera más eficiente, aunque ambos aspectos son importantes. El desarrollo representa una transformación de la sociedad. El Consenso de Washington hizo caso omiso de estas dimensiones. De cierto modo creía que si permitíamos que los mercados funcionaran solos, los países lograrían desarrollarse. Eso no ha sucedido y nunca antes sucedió. Sin embargo, se alentó o se obligó a los países a centrar la atención en un programa económico restringido -y por ende equivoca- do- - y de esa manera se perdieron de vista los objetivos más amplios de la reforma social, en la que habrían tenido mayor relieve la reforma agraria, la educación y los derechos políticos y económicos.

Hoy en día reconocemos la estrecha vinculación que existe entre los procesos económicos, sociales y políticos. Se examinan abiertamente los problemas que plantean los distintos regímenes políticos. Sin embargo, no se ha prestado la debida atención al papel que desempeñan las políticas -incluidas las políticas económicas- en la configuración del régimen político, ni a las repercusiones que tuvo en el proceso político la manera en que se impusieron las reformas. En Rusia, algunos impulsaron la idea de la privatización rápida, sin preocuparse por la forma en que se haría, en la ingenua convicción (a la que me he referido como el teorema político de Coase) de que, una vez que el Estado renunciara al control de los derechos de propiedad privada, prevalecería el imperio de la ley. Ello no sucedió, como era de prever. No fue Rockefeller quien promovió las leyes antimonopólicas a fines del siglo XIX, y no ha sido Gates el que ha preconizado la aplicación efectiva de dichas leyes hoy en día. De hecho, ha habido intentos incluso de recortar los fondos destinados a la aplicación efectiva de las leyes antimonopólicas por parte de los que podrían verse perjudicados. Ha sido, y sigue siendo, la clase media la que ha apoyado con mayor ahínco el imperio de la ley, ${ }^{65} \mathrm{y}$ ha sido la clase media la que ha sido devastada por algunas de las políticas del Consenso de Washington.

Si el desarrollo es en efecto la transformación de la sociedad, debemos reflexionar cuidadosamente sobre lo que entraña esa transformación y pensar en el modo de promoverla más eficazmente. La agenda de reforma neoliberal ni siquiera logró sus objetivos más limitados de promoción del crecimiento. Al pensar en las medidas que deberían reemplazarlo, es preciso que nos alejemos de la visión estrecha en que se inspiraba ese programa. $\mathrm{Al}$ reformar la agenda económica, tendremos que ubicarla dentro del contexto más amplio en que debe morar.

(Traducido del inglés)
${ }^{64}$ Por ejemplo, la observación de que existen problemas en el sis-
tema público de pensiones no significa que debamos privatizar. No
debemos comparar un sistema privado idealizado con el sistema
público real. En la práctica, los costos de transacción, incluso en
los países industrializados avanzados, han sido enormes. Quizás sea más fácil mejorar el sistema público que crear un sistema privado, con todo el aparato normativo necesario. Véase, por ejemplo, Orszag y Stiglitz (2001) y Murthi, Orszag y Orszag (1999).

${ }^{65}$ Ver Birdsall, Graham y Pettinato (2000). 
Agénor, P. (2002): Macroeconomic Adjustment and the Poor: Analytical Issues and Cross-Country Evidence, Policy Research Working Paper, $\mathrm{N}^{\circ}$ 2788, Washington, D.C., Banco Mundial, agosto.

Akerlof, G., W. Dickens y G. Perry (1996): The macroeconomics of low inflation, Brookings Papers on Economic Activity, vol. 1, Washington, D.C., The Brookings Institution.

Baily, M., J. Stiglitz y L. Tyson (1995): Economic Report of the President 1994, Washington, D.C., Government Printing Office.

Banco Mundial (varios años), Indicadores de desarrollo mundial, Washington, D.C.

(2000): World Development Report, 2000/2001: Attacking Poverty, Nueva York, Oxford University Press.

Birdsall, N., C. Graham y S. Pettinato (2000): Stuck in the Tunnel: Have New Markets Muddled the Middle Class?, Center on Social and Economic Dynamics Working Paper, $N^{\circ} 14$, Washington, D.C., The Brookings Institution, agosto.

Bouillon, C., A. Legovini y N. Lustig (2001): Rising Inequality in Mexico: Household Characteristics and Regional Effects, Washington, D.C., Departamento de Desarrollo Sostenible, Banco Interamericano de Desarrollo (BID), septiembre.

Caprio, G. y D. Klingebiel (1999): Episodes of Systemic and Borderline Financial Crises, World Bank Discussion Paper, Washington, D.C., Banco Mundial, octubre.

Card, D. y A. Krueger (1995): Myth and Measurement: The New Economics of the Minimum Wage, Princeton, Princeton University Press.

CEPAL (Comisión Económica para América Latina y el Caribe) (2002a): Situación y perspectivas, 2002. Estudio económico de América Latina y el Caribe, 2001-2002, LC/G.2184-P, Santiago de Chile, agosto. Publicación de las Naciones Unidas, $\mathrm{N}^{\mathrm{o}}$ de venta: S.02.II.G.71.

(2002b): Globalización y desarrollo, LC/G.2157(SES.29/3), Santiago de Chile, abril.

(2002c): Panorama social de América Latina, 2001-2002, LC/G.2183-P, Santiago de Chile. Publicación de las Naciones Unidas, $\mathrm{N}^{\mathrm{o}}$ de venta: S.02.II.G.65.

Council of Economic Advisers (1996): Economic Report of the President, Washington, D.C., Government Printing Office.

(1997): Economic Report of the President, Washington, D.C., Government Printing Office.

Damill, M. y R. Frenkel (2003): Argentina: macroeconomic performance and crisis, en R. Ffrench-Davis, D. Nayyar y J.E. Stiglitz (comps.), Stabilization Policies for Growth and Development, Nueva York, Initiative for Policy Dialogue, Macroeconomics Task Force, por aparecer (www.policydialogue.org).

Dasgupta, P. (1995): An Inquiry into Well-Being and Destitution, Oxford, Clarendon Press.

Dasgupta, P. y J. Stiglitz (1988): Learning by doing, market structure and industrial and trade policies, Oxford Economic Papers, vol. 40, No 2, Oxford, Oxford University Press.

De Gregorio, J. y J. Lee (1999): Economic Growth in Latin America: Sources and Prospects, Documentos de trabajo, N ${ }^{\circ} 66$, Santiago de Chile, Centro de Economía Aplicada, Universidad de Chile.

Dougherty, C. y D.W. Jorgenson (1997): There is no silver bullet: investment and growth in the G7, National Institute Economic Review, No 162, Londres, Sage Publications Ltd., octubre.

Easterly, W., R. Islam y J.E. Stiglitz (2000): Shaken and stirred: explaining growth volatility, Annual Bank Conference on Development Economics 2000, Washington, D.C., Banco Mundial. (Publicado también en Jacques Drèze (comp.), Advances in Macroeconomic Theory, IEA Conference, vol. 133, Houndsmill, Palgrave, 2001.)
Fisher, I. (1933): The debt deflation theory of great depressions, Econometrica, vol. 1, $\mathrm{N}^{\circ}$ 4, Evanston, The Econometric Society, octubre.

Ffrench-Davis, R. (2003a): Domestic macropolicies and financial crisis: a view from emerging economies, en R. Ffrench-Davis, D. Nayyar y J.E. Stiglitz (comps.), Stabilization Policies for Growth and Development, Nueva York, Initiative for Policy Dialogue, Macroeconomics Task Force, por aparecer (www.policydialogue.org).

(2003b): Macro-economic balances in Latin America: the conflict between purely-financial and real-economy imbalances, en R. Ffrench-Davis, D. Nayyar y J.E. Stiglitz (comps.), Stabilization Policies for Growth and Development, Nueva York, Initiative for Policy Dialogue, Macroeconomics Task Force, por aparecer (www.policydialogue.org).

Furman, J. y J.E. Stiglitz (1998a): Economic crises: evidence and insights from East Asia, Brookings Papers on Economic Activity, $\mathrm{N}^{\mathrm{o}}$ 2, Washington, D.C., Brookings Institution Press. (1998b): Economic consequences of income inequality, Symposium Proceedings. Income Inequality: Issues and Policy Options, Jackson Hole, Wyoming, Federal Reserve Bank of Kansas City.

Greenwald, B. (1999): International adjustment in the face of imperfect financial markets, en B. Pleskovic y J.E. Stiglitz (comps.), Annual World Bank Conference on Development Economics, 1998, Washington, D.C., Banco Mundial.

Greenwald, B. y J.E. Stiglitz (1986): Externalities in economies with imperfect information and incomplete markets, Quarterly Journal of Economics, vol. 101, N $\mathrm{N}^{\circ}$ 2, Cambridge, Massachusetts, The MIT Press, mayo.

(1993): New and old Keynesians, Journal of Economic Perspectives, vol. 7, $\mathrm{N}^{\circ}$ 1, Nashville, Tennessee, American Economic Association.

Hardin, Garrett (1995): La tragedia de los comunes, Gaceta Ecológica, $\mathrm{N}^{\circ} 37$, Instituto Nacional de Ecología, México, D.F., http://www.ine.gob.mx.

Helmann, T., K. Murdoch y J.E. Stiglitz (2000): Liberalization, moral hazard in banking and prudential regulation: are capital requirements enough, The American Economic Review, vol. 90, No 1, Nashville, Tennessee, American Economic Association, marzo.

Honohan, P. y J.E. Stiglitz (2001): Robust financial restraint, en G. Caprio, P. Honohan y J.E. Stiglitz (comps.), Financial Liberalization: How Far, How Fast?, Cambridge, Cambridge University Press.

Kane, E.J. (1989): The S\&L Insurance Mess: How Did It Happen?, Washington, D.C., Urban Institute Press.

Krug, B.G. (comp.) (2002): World Report on Violence and Health, Ginebra, Organización Mundial de la Salud (OMS).

Murthi, M., J.M. Orszag y P.R. Orszag (1999): The Charge Ratio on Individual Accounts: Lessons from the U.K., Birbeck College Working Paper 99-2, Londres, Universidad de Londres, marzo.

Newbery, D. y J.E. Stiglitz (1984): Pareto inferior trade, The Review of Economic Studies, vol. 51, No 1, Oxford, The Review of Economic Studies Ltd., enero.

Ocampo, J.A. (2002): Media década perdida, Notas de la CEPAL, $\mathrm{N}^{\circ} 24$, Santiago de Chile, CEPAL, septiembre.

ops (Organización Panamericana de la Salud) (1996): La violencia en las Américas: la pandemia social del siglo XX, Washington, D.C.

Orszag, P. y J.E. Stiglitz (2001): Rethinking pension reform: ten myths about social security systems, en R. Holman y J.E. Stiglitz (comps.), New Ideas About Old Age Security: Toward Sustainable Pension Systems in the $21^{\text {st }}$ Century, Washington, D.C., Banco Mundial. 
PNUD (Programa de las Naciones Unidas para el Desarrollo) (varios años): Informe sobre desarrollo humano, Nueva York, Naciones Unidas.

Prasad, E., K. Rogoff y otros (2003): Effects of Financial Globalization on Developing Countries: Some Empirical Evidence, Washington, D.C., Fondo Monetario Internacional, marzo (www.imf.org).

Rao, V. y M. Walton (comps.) (2003): Culture and Public Action: How Cultural Factors Affect an Unequal World, Stanford, California, Stanford University Press, por aparecer.

Rodrik, D. (1998): Who needs capital-account convertibility?, en Stanley Fischer y otros (comps.), Should the IMF Pursue Capital-Account Convertibility?, Princeton Essays in International Finance, $N^{\circ}$ 207, Princeton, Princeton University, mayo.

Rodrik, D. y F. Rodríguez (2001): Trade policy and economic growth: a skeptic's guide to the cross-national evidence, en B. Bernanke y K.S. Rogoff (comps.), NBER Macroeconomics Annual 2000, Cambridge, Massachusetts, The MIT Press.

Rodrik, D. y A. Velasco (1999): Short-Term Capital Flows, NBER Working Paper, $\mathrm{N}^{\mathrm{o}}$ 7364, Cambridge, Massachusetts, National Bureau of Economic Research (NBER), septiembre.

Sappington, D. y J.E. Stiglitz (1987): Privatization, information and incentives, Journal of Policy Analysis and Management, vol. 6, $\mathrm{N}^{\mathrm{o}}$ 4, Nueva York, John Wiley and Sons.

Shiller, R.J. (2000): Irrational Exuberance, Princeton, Princeton University Press, abril.

Simon, H.A. (1991): Organizations and markets, Journal of Economic Perspectives, vol. 5, $\mathrm{N}^{\circ}$ 2, Nashville, Tennessee, American Economic Association.

Soros, G. (2002): George Soros on Globalization, Nueva York, Public Affairs.

Stiglitz, J.E. (1996): Some lessons from the East Asian miracle, World Bank Research Observer, vol. 11, № 2, Washington, D.C., Banco Mundial, agosto. (Reimpreso como Algunas enseñanzas del milagro del Este Asiático, Desarrollo económico, vol. 37, $\mathrm{N}^{\circ}$ 147, Buenos Aires, Instituto de Desarrollo Económico y Social (IDES), octubre-diciembre de 1997). (1997): Reflections on the natural rate hypothesis, Journal of Economic Perspectives, vol. 11, No 1, Nashville, Tennessee, American Economic Association.

(1998): Towards a new paradigm for development: strategies, policies and processes, $9^{\text {th }}$ Raul Prebisch Lecture, Ginebra,
Conferencia de las Naciones Unidas sobre Comercio y Desarrollo (UNCTAD), 19 de octubre. (Publicado también en H. Chang (comp.), The Rebel Within, Londres, Wimbledon Publishing Company, 2001).

(1999a): Reforming the global economic architecture: lessons from recent crises, The Journal of Finance, vol. 54, $\mathrm{N}^{\circ}$ 4, Oxford, Blackwell Publishers, agosto.

(1999b): Lessons from East Asia, Journal of Policy Modeling, vol. 21, $\mathrm{N}^{\circ} 3$, Amsterdam, Elsevier Science Publishers, mayo.

(1999c): Must financial crises be this frequent and this painful?, Policy Options, vol. 20, No 5, Montreal, Institute for Research on Public Policy (IRPP), junio.

(1999d): Taxation, public policy and the dynamics of unemployment, International Tax and Public Finance, vol. 6, Boston, Swets \& Zeitlinger.

(2000a): Capital market liberalization, economic growth and instability, World Development, vol. 28, $\mathrm{N}^{\circ} 6$, junio.

(2000b): Lessons from the global financial crisis, en J.R.

Bisignano, W.C. Hunter y G.G. Kaufman (comps.), Global Financial Crises: Lessons from Recent Events, Boston, Kluwer Academic Publishers.

(2001a): Principles of financial regulation: a dynamic approach, The World Bank Observer, vol. 16, No 1, Washington, D.C, Banco Mundial.

(2001b): Participation and development: perspectives from the comprehensive development paradigm, en F. Iqbal y J-I.You (comps.), Democracy, Market Economics and Development: An Asian Perspective, Washington, D.C., Banco Mundial. (Publicado también en H-J. Chang (comp.), The Rebel Within, Londres, Wimbledon Publishing Company, 2001).

(2002a): Capital market liberalization and exchange rate regimes: risk without reward, The Annals of the American Academy of Political and Social Science, vol. 579, Londres, Sage Publications Ltd., enero.

(2002b): El malestar en la globalización, Buenos Aires, Taurus.

(2003): The Roaring 90s, Nueva York, W.W. Norton.

Wolfensohn, J.D. (1998): "The Other Crisis," discurso pronunciado en la Junta de Gobernadores del Banco Mundial y el Fondo Monetario Internacional, Reuniones Anuales, Washington, D.C., 6 de octubre. 